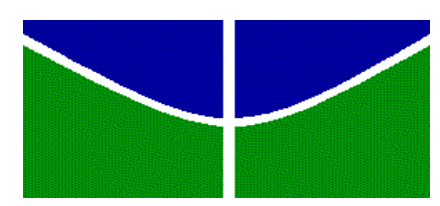

Universidade de Brasília

Departamento de Linguística, Português e Línguas Clássicas

\title{
O TRIÂNGULO CANDANGO: \\ Tu, Você e Cê em Estudo Sociolinguístico
}

LUCAS ARYEL MENDES ABREU

BRASÍLIA 
UNIVERSIDADE DE BRASÍLIA - INSTITUTO DE LETRAS

DEPARTAMENTO DE LINGÜÍSTICA, LINGUAS CLÁSSICAS E PORTUGUÊS- LIP

\section{O TRIÂNGULO CANDANGO: \\ Tu, Você e Cê em Estudo Sociolinguístico}

Lucas Aryel Mendes Abreu

Trabalho de Conclusão de Curso apresentado ao Departamento de Linguística, Português e Línguas Clássicas da Universidade de Brasília (UnB), como requisito parcial para a obtenção do grau de Licenciado em Letras.

ORIENTADORA: Professora Doutora Ulisdete Rodrigues de Souza Rodrigues

BRASÍLIA, 2017 
Dedico todas as minhas palavras

Àquele que é digno de toda honra e glória; À Zinha, minha, a mais perfumada pétala dos jardins Celestinais; Ao Home Véio, bruta flor, paizão companheiro; À Tininha, vanguardista, inspiração. Incrível; Ao Alex, tão distante, tão presente. Artista; À Uli, compreensiva, educadora. Singela, dissílaba; Aos litros de café, risadas e lágrimas divididos com Ronan, nervo exposto, gênio, indomável; A N., chuva oblíqua, poesia. 


\section{RESUMO}

O presente trabalho trata da variação entre as formas pronominais tu, você e cê na variedade brasiliense do português falado, com enfoque nas regiões de Taguatinga e Plano Piloto, examinando as características discursivas e gramaticais que envolvem a produção dessas formas pronominais entre os falantes das duas regiões focalizadas. Utilizando-se do método sociolinguístico quantitativo para a realização das análises, a pesquisa visa o mapeamento dessas variantes pronominais de segunda pessoa no Distrito Federal, levando em consideração os aspectos linguísticos e sociais envolvidos na produção das referidas formas dentre os falantes das regiões em destaque. As referências teóricas básicas desta pesquisa são os estudos de Faraco (1991; 2008), Andrade (2010), Scherre $(2011 ; 2012)$, dentre outros. Ao final desse estudo, aferir-se-á que a variação entre as formas tu, você e cê no falar brasiliense, de fato, será mais ou menos acirrada, mais ou menos bem avaliada, a depender da localidade e do sexo/gênero dos falantes envolvidos, bem como da estrutura linguística proferida, constituindo a variável dependente contemplada neste estudo mais um caso de variação linguística em franca expansão no coração político do Brasil Central.

Palavras-Chave: Pronome; Variação; Sociolinguística. 


\begin{abstract}
This work concerns the variation between the "tu", "você" and "cê" forms in the brasiliense variety of spoken portuguese, with a focus on the regions of Taguatinga and Plano Piloto, examining the discursive and grammatical characteristics that involve the use of these pronominal forms among the speakers in both of these regions. Using the sociolinguistic quantitative method for analytical procedures, the research aims to map these secondperson pronominal variants in Distrito Federal, taking into consideration the linguistical and social aspects involved in the production of said forms among the speakers of the forms in the aforementioned regions. The basic theoretical references of this work are the studies of Faraco (1991; 2008), Andrade (2010), Scherre (2011; 2010), among others. At the conclusion of this study, it will be inferred that the variation between the forms "tu", "você" and "cê" in the brasiliense speech, in fact, will depend of the locality and the sex or gender of the speakers involved, as well as the linguistic structure of the period, being the dependent variable focused in this study one more case of expansion of linguistic variation on the political core of Central Brazil.
\end{abstract}

Key Words: Pronoun; Variation; Sociolinguistics. 


\section{SUMÁRIO}

1. Palavras Iniciais, 6

2. Metodologia, 9

2.1. Contextualização Teórico-Prática, 9

2.2. O Ambiente de Estudo, 13

3. Arcabouço Teórico, 16

3.1. Elementos da Sociolinguística, 16

3.1.1. Variação, 16

3.1.2. Mudança, 17

3.1.3. Norma, 18

3.1.4. Preconceito, 19

3.2. Revisão da Literatura sobre o Fenômeno em Foco, 21

3.2.1. Tu, Você e Cê na história, 21

3.2.2. Tu e Você em Obras Tradicionais, Linguísticas e Sociolinguísticas, 22

3.2.3 Tu, Você e Cê no DF e arredores, 24

4. Análise dos Dados, 26

4.1. Elementos Condicionantes do Fenômeno, 26

4.1.1. Variáveis Sociais, 26

4.1.2. Variáveis Linguísticas, 30

4.1.3. Cruzamento das Variáveis, 35

4.1.3.1. Posição Sintática, 35

4.1.3.2. Tipo de Construção

4.1.3.3. Tipo de Discurso, 42

5. Considerações Finais, 45

Bibliografia, 47 
"E Sabina nele via, a cada vez, um novo rio correndo, um rio semântico: o mesmo objeto suscitava a cada vez um outro significado, mas esse significado repercutia (como num eco, num cortejo de ecos) todos os significados anteriores. O que estava sendo vivido ressoava com uma harmonia cada vez mais rica" - Milan Kundera

\section{PALAVRAS INICIAIS}

Talvez, a mais fascinante faculdade do ser humano seja a linguagem, que nos acompanha desde os primórdios das civilizações, sendo um dos mais importantes - se não o mais - meios de desenvolvimento e manutenção da vida humana. A capacidade de se comunicar emerge do cerne do ser humano, seja pela sua capacidade cognitiva ou pela necessidade de uma interação além do simples contato com outros seres. A partir daí, surge a necessidade de codificação dessa linguagem, algo que possa ser tido como um sistema linguístico no qual sejam possíveis e resguardadas suas propriedades, visando o aprimoramento da comunicação entre aqueles que utilizem esse código.

Datam do século VII a.C. os primeiros registros conhecidos em Latim, língua indoeuropeia falada na região do Lácio, adotada como oficial pelo Império Romano, e que, a partir de sua expansão, propagou-se pelas regiões conquistadas, variando e mudando, servindo, assim, de base para a formação de diversas outras línguas, que variaram de acordo com a região, as chamadas "línguas neo-latinas", dentre as quais encontra-se o Português.

Percebe-se, portanto, que processos históricos e sociais têm papel fundamental em se tratando da língua, tanto em sua variação, quanto em sua formação, aplicando-se a mesma lógica de mudança e variação do Latim ao Português, o qual, a partir da expansão ultramarina mercantilista dos anos tardios da Idade Média, propagou-se pelo mundo (mudando aspectos para atender às necessidades e especificidades dos grupos ali residentes - os quais já tinham seus próprios códigos, mas servindo como superstrato linguístico, variando de acordo com essas especificidades preexistentes), chegando, assim, ao Brasil, país que tem a Língua Portuguesa como oficial.

Entretanto, como já tangenciado, a própria língua varia e muda em si mesma por conta do contexto geográfico e histórico, e o Português do Brasil não foge a essa regra. $\mathrm{A}$ partir de diversos processos históricos, geográficos, políticos e sociais, internamente, 0 Português do Brasil desenvolveu-se ao longo da história do país, a ponto de ser possível e 
necessário, o estudo focalizado dos fenômenos variacionais ocorrentes em seu sistema. Assim sendo, observando o contexto de formação da capital brasileira nos anos 1950 quando diversos trabalhadores, com seus costumes e falares encontraram-se no Planalto Central para a construção dessa nova capital, o presente trabalho trata do uso das formas pronominais TU, VOCÊ e CÊ no falar dos moradores de duas regiões administrativas do Distrito Federal: Brasília e Taguatinga, as quais resguardam processos específicos de formação e constituição social, os quais refletem tanto os construtos sociais que levaram ao desenvolvimento interno do "falar candango" quanto os preexistentes, que o influenciaram, e, consequentemente, reverberaram nele.

A escolha de tal tema deu-se pela percepção de diferenças de alternância e posição dos pronomes pessoais retos de $2^{2}$ pessoa do singular no falar candango ${ }^{1}$, que variam de acordo com diversos fatores envolvidos no contexto social e de fala.

Daí, torna-se o objeto desafiador, pois a identificação desses fatores que levam à variação pode evidenciar tanto as relações que existem nas escolhas de uso de tais formas por parte dos falantes, quanto quais são as variáveis envolvidas em sua utilização, suscitando aspectos econômicos, sociais e geracionais - o enfoque maior desta pesquisa. Contribuindo para um "mapeamento" dos contextos de produção das formas pronominais, e servindo de panorama desse aspecto no falar candango.

Ou seja, o objetivo geral do trabalho pode ser traduzido na busca pelas marcas de utilização das formas, seus contextos, posições e ambientes, visando, especificamente, o mapeamento dos fatores linguísticos, históricos e sociais envolvidos na produção das referidas formas pronominais.

Esses fatores suscitam perguntas como se a classe social do falante, sexo, idade e ambiente e contexto de fala influenciam na produção de uma ou outra forma pronominal, ou se há, dentre elas, alguma mais prestigiada, e qual o contexto de sua produção, além de questionar se as diferentes gerações de brasilienses influenciam o aspecto pronominal do falar candango, observadas as diversas variáveis dessa variante da língua, e as especificidades de sua evolução, tanto num plano de variação e mudança geral de línguas quanto num recorte específico dessa região.

O trabalho será estruturado em, além das palavras iniciais, quatro principais partes, divididas por capítulos, na seguinte ordem: Metodologia, que tratará da contextualização tanto do fenômeno, quanto do estudo sociolinguístico quantitativo; Arcabouço Teórico, que tratará das obras canônicas, linguísticas e sociolinguísticas, encaixando o fenômeno dentro de um sistema linguístico e observando-o como relacionado a aspectos condicionantes de 
produção históricos e sociais, além de linguísticos; Análise dos Dados, momento no qual serão apresentados, discutidos e avaliados os dados coletados na presente pesquisa; e, por fim, as Considerações Finais, momento no qual serão apreciados os fatores relacionados à produção do trabalho e haverá, ainda, a avaliação conclusiva do estudo aqui desenvolvido. 
"Ah mais cê veja

num me resta mais creto

prá um furnicimento só eu caino

nas mãos do véi Brolino

mêrmo a deis pur cento

é duro môço

ritirá prum trecho alei

c'ua pele no osso e as alma

nos bolso de véi

me ispera, assunta viu

sô imbuzêro das bêra do rio

conforma num chora mulé

eu volto se assim Deus quisé

num dêxa o rancho vazio

eu volto prás curva do rio."

- Elomar Figueira Mello

\section{METODOLOGIA}

Esta parte do trabalho traçará um breve histórico da Sociolinguística, observando seus pressupostos e contextualizando-a perante os estudos de humanidades. Ainda, disporá da Teoria Variacionista, metodologia basilar para as análises aqui constantes, e suas características. Logo após, será feita a focalização dos ambientes a serem estudados, contextualizando-os social e historicamente, falando, ainda, do modelo de observação utilizado, discriminando seus fatores constituintes. Por fim, destacará o fenômeno a ser estudado, e a motivação para o estudo dele.

\subsection{CONTEXTUALIZAÇÃO TEÓRICO-PRÁTICA}

A Sociolinguística surge em meados dos anos 1960 nos Estados Unidos, quando diversos linguistas - dentre os quais destaca-se William Labov, proponente da Teoria da Variação, fascinados pelas relações entre língua e sociedade, e apoiados nos estudos linguísticos do mesmo século, propuseram uma linha teórica mais restrita a essa relação tão imbricada entre estrutura linguística e estrutura social. É fato que ambas estruturas têm suas especificidades, entretanto, partindo dos pressupostos subjetivos das ciências humanas e observando a língua como um construto da sociedade, e sua estruturação e codificação 
como parte desse organismo social, inegável é a relação que constitui-se entre ambos aspectos uma espécie de "construto indivisível" da vivência humana.

A língua é um produto, acordo social, segundo Sausurre - pai do estruturalismo e um dos precursores das grandes linhas teóricas da linguística, resultado das relações e do desenvolvimento das civilizações, e, ainda, para Cohen, outro teórico precursor das mesmas teorias, é inconcebível o aspecto linguístico sem o social, reciprocamente. Portanto, pode ser classificada a língua como uma manifestação concreta do ato de vivência do ser humano, de sua organização e necessidades: serve a língua ao homem, e vice e versa. Portanto, o objeto de estudo da Sociolinguística traduz-se na necessidade de estabelecimento das relações entre sujeito e contexto, onde os fatores específicos dos grupos linguísticos analisados refletem a organização, história, contexto social e relações entre seus participantes. Ou seja, ocupa-se a Sociolinguística de observar, analisar e compreender cada um dos aspectos que envolvem o uso e desenvolvimento da Língua, em todas as dimensões que os sentidos individuais e sociais podem abarcar.

Os fenômenos linguísticos são observados, para a Sociolinguística, como movimentos naturais do organismo complexo que compõe a língua, sendo assim, a o estudo da sociolinguística fora idealizado por seus precursores visando o atendimento de especificidades inerentes às complexas relações que dão-se na engrenagem línguasociedade, preenchendo, assim, lacunas que, até então, não haviam sido completadas no seio do estudo linguístico. Portanto, o estudo sociolinguístico tem contribuído, desde sua postulação, com importantes avanços no âmbito da observação dos diferentes fenômenos de variação e mudança das línguas, levando em consideração todos os aspectos de sua estruturação, analisando os contextos reais de fala, e suas nuances, como a indução de fala monitorada ou discurso reportado. Assim, as relações entre fatores linguísticos e extralinguísticos servem de base para a sociolinguística, grande contribuidora dos estudos da linguística moderna.

O estudo sociolinguístico tem como pressupostos básicos os conceitos de Variação e Mudança. A primeira, observa, tanto sincrônica quanto diacronicamente, como a língua varia, guardando o fato de a língua ser um legado histórico, um conjunto de aspectos linguísticos que competem em diferentes âmbitos e aspectos, os quais variam de acordo com fatores como idade, gênero, sexo, contexto de fala, ou, ainda, as diferenças geográficas de produção de uma mesma língua, contexto de formação e variação específicos inerentes àquela variedade; ou seja, diferenças de uso, de forma, produção e contexto podem ser interpretadas à luz da Variação. 
Já a Mudança, observa como as línguas humanas mudaram com o tempo, quais formas foram as "escolhidas" no complexo jogo entre mutação e permanência linguística. Todos os aspectos de uma língua podem mudar, e a Mudança toma exatamente essa premissa como preponderante para a compreensão da fenomenologia linguística bem como dos estudos da língua, por isso deve haver a observância, em textos antigos ou falares de grupos excluídos, por exemplo, de quais foram os aspectos que sofreram mudança. Toda língua muda, e seus fenômenos internos, morfológicos, sintáticos, semânticos, têm grande valia na compreensão da evolução das línguas. Nessa direção, acrescenta-se que:

Um estudo sociolinguístico visa à descrição estatisticamente fundamentada de um fenômeno variável, tendo como objetivo analisar, apreender e sistematizar variantes linguísticas usadas por uma mesma comunidade de fala. Para tanto, calcula-se a influência que cada fator, interno ou externo ao sistema linguístico, possui na realização de uma ou de outra variante (LUCCHESI, in. http://www.vertentes.ufba.br/a-teoria-da-variacao-linguistica).

Sendo a Sociolinguística o estudo do comportamento linguístico dentro de uma comunidade de fala, apropriando-se de suas diversas facetas, lida ela, portanto, com a heterogeneidade dos sistemas, seu contexto de utilização e as variáveis do processo, sejam elas internas ou externas ao código linguístico focalizado. Portanto, entende-se que os processos de mudança linguístico perpassam os diversos sistemas do invólucro social e passam por variações internas, as quais explicam tal fenômeno.

Então, pode-se inferir que dentro de uma mesma língua há diversas formas que coocorrem (formas que acontecem ao mesmo tempo) e concorrem (formas que concorrem em utilização) em utilização, e a busca da sistematização desse sistema, em contraponto ao aparente "caos linguístico", é objeto central do estudo sociolinguístico. Tal sistematização apenas é possível a partir da adoção de algum parâmetro de observação, e para tal, neste trabalho, será utilizada a Teoria Variacionista ou Teoria da Variação, a qual apregoa justamente tais conceitos de concorrência e coocorrência supracitados, e analisa as diversas variantes dos fenômenos ocorrentes, as quais, em conjunto, constituem o que se chama variável linguística - que pode ser (i) Dependente (analisa o fenômeno observando o conjunto de variantes em competição que compõem tal variável) ou (ii) Independente (ou seja, os fatores linguísticos estruturais ou sociais observáveis que motivam a utilização das variantes constantes nessa variável) - buscando traçar quais os fatores de caracterização dos diversos processos existentes nos fenômenos de variação e mudança pelos quais passa uma língua. Apenas observando as relações que existem entre os diferentes grupos da sociedade, com uma ou outra característica específica, partilhando da convivência social, 
até certo ponto, mas diferindo em fatores biológicos, por exemplo, ou étnicos, pode-se ter noção da "rede" de influências da qual participa o ato de produção do código linguístico.

Cabe, portanto, ao sociolinguista observar e compreender quais são os contextos que favorecem a variação, e quais suas especificidades. Ou seja, o papel do sociolinguista é como o de um "investigador" da língua, o qual necessita de aparato teórico, metodológico e conhecimento histórico e geográfico dos grupos que observa, pois, o contexto social, propriamente dito, em todas as suas dimensões, evidencia o que está acontecendo em cada contexto situacional - maior responsável pela variação.

Apenas a partir do desembaraço desse emaranhado linguístico que é o terreno da variação, e analisadas as variantes panoramicamente, pode-se observar a sistematização desse "universo" linguístico, que parte de fatores internos e externos ao próprio ato linguístico, quebrando com a cisão estruturalismo $x$ gerativismo, tendendo a observar a língua como um organismo vivo, cheio de nuances e vertentes, o qual não exclui nenhum de seus fatores constituintes, fatores esses que demonstram cada vez mais que uma cisão entre língua e sociedade é equivocado, bem como uma análise que observe exclusivamente o sujeito, incompleta, pois, de acordo com o pensamento básico laboviano, não se pode compreender a língua fora do contexto social.

A presente pesquisa apoiar-se-á em pesquisa de campo, visando a coleta de corpus falado, gravado em situações formais e informais de fala, com momentos de fala monitorada, de modo que as mais variadas facetas do contexto interacional vernacular sejam abordados e descritos. A coleta de dados fora realizada nas duas regiões descritas a seguir, e considerou os seguintes critérios para a constituição de uma amostra estruturada dos fenômenos: 1. Sexo; 2. Localidade.

A escolha dos informantes com base nos critérios descritos motiva-se pela hipótese de que tais fatores se mostram como suficientes para a postulação da hipótese de que eles influenciam na ocorrência e estruturação das formas estudadas. Vale ressaltar que é o aspecto geracional, sem dúvidas, um dos mais importantes fatores relacionados à produção de língua. $O$ fator geração ajuda a compreender os processos de mudança que acontecem com a língua através dos tempos, e as escolhas linguísticas que os diversos grupos, comunidades de fala, fazem. Assim, esse espectro de análise é preponderante para compreender a situação de uso da língua portuguesa nas comunidades focalizadas, e, ainda, no caso específico desse trabalho, do surgimento de uma variante específica do falar candango, dado o contexto histórico dessa região. Nesse sentido, a presente pesquisa tem foco nos falantes nascidos entre os anos de 1990 e 1999, ou seja, uma geração de faixa etária intermediária de falantes, visando observar quais as principais características 
linguísticas do grupo de falantes brasilienses de terceira geração. Tal conjunto compõe uma comunidade de fala de idade intermediária no momento de coleta dos dados do trabalho, aspecto preponderante para sua escolha como foco de colhimento de dados, se observados os aspectos de variação e mudança levados em consideração para a pesquisa sociolinguística, amplamente discutidos por Faraco, e abordados no próximo capítulo desta pesquisa.

Diante da exposição dos fatores que levaram à escolha dos informantes e do método a ser utilizado para levantamento de corpus, lancemos olhar, nesta próxima parte do trabalho, a um breve histórico das duas cidades escolhidas para a análise, para compreensão dos aspectos que motivaram sua escolha.

\subsection{O AMBIENTE DE ESTUDO}

No que se refere ao ambiente de estudo, duas foram as regiões escolhidas para enfoque, com base em sua formação e disparidade de perfis de habitantes: Brasília e Taguatinga. A primeira, também chamada de Plano Piloto, é a Região Administrativa I do Distrito Federal, inaugurada em 21 de abril de 1960, mesma data de inauguração da nova capital, compreendendo, ao menos neste trabalho, os bairros Asa Norte, Asa Sul e imediações desses. Centro Administrativo do país, essa região que, de acordo com o último censo, tem aproximadamente 216 mil habitantes, é uma das regiões mais abastadas da capital brasileira. Importante é frisar que o nome "Brasília" não se refere ao "quadrado" do Distrito Federal como um todo, mas sim, a uma Região Administrativa específica que, neste trabalho, será representada, e abrangerá, apenas os bairros supracitados e suas adjacências.

Brasília tem um contexto de formação bastante privilegiado: como uma cidade planejada, abrigou nos primeiros anos de existência, sobretudo, funcionários do governo, sendo boa parte das habitações previstas no projeto original, apartamentos funcionais, os quais após os anos 70, principalmente, começaram a ser ocupados pela parte da população estabelecida no DF disposta a pagar para estar mais perto do grande Centro Administrativo. A proximidade dos prédios públicos e o alto investimento no planejamento da cidade, que englobou diversos aspectos como trânsito, segurança pública, funcionalidade dos blocos e locais de diversão, o Plano Piloto consolidou-se como uma região habitada por pessoas de maior poder aquisitivo, fator corroborado pelo seu alto Índice de Desenvolvimento Humano, um dos maiores do país, passando dos 0,95 pontos. Seus fatores de formação e sucessivo investimento, por parte do Estado para manutenção da região como um "modelo", fazem 
desta região um importante nicho para compreender os fenômenos linguísticos ocorrentes no falar candango, pois, além de seus fatores formadores, com um baixo influxo de habitantes (devido ao alto valor das habitações, é comum perceber diversas famílias que mantém-se por várias gerações no mesmo lugar, ou, ainda, poucas pessoas dispostas a deixar a região em detrimento de outras no DF) alto poder aquisitivo e maior nível de escolaridade - fatores de refreamento da mudança linguística -, em sua maioria, dos mesmos, é possível traçar interessante paralelo com a segunda cidade escolhida para análise: Taguatinga, a qual baseou-se em outro tipo de constituição, e na qual reside população que difere cabalmente da primeira focalizada.

Criada com o intuito de diminuir o grande número de invasões de trabalhadores candangos, Taguatinga fora inaugurada em 1958, dois anos antes do término da construção da grande capital. Inicialmente chamada de Vila Sarah Kubitschek - tendo seu nome mudado nos anos 70 pelo governador Hélio Prates, prestando homenagem ao nome da fazenda que ocupava o território da atual região (nome esse, ainda, resultado do processo de assimilação dos termos ta'wa e tinga, usado pelos indígenas que ali habitavam em épocas remotas para caracterizar a área), essa, hoje, é a Região Administrativa III do Distrito Federal, e sua criação remete ao período de consolidação de vários dos trabalhadores que foram executar o plano de construção da capital brasileira, e lá quiseram instalar-se. O governo, percebendo as dispersas invasões criadas por esses mesmos trabalhadores, tratou de criar uma Vila, situada a $19 \mathrm{~km}$ do grande Centro Administrativo, o Plano Piloto, para redirecioná-los. Em pouco tempo, o comércio consolidou-se na região, trazendo diversos avanços para a área, e atraindo mais pessoas para ali viver. Assim deuse a expansão de Taguatinga, a primeira cidade-satélite, que de acordo com o último censo, conta com aproximadamente 215 mil moradores, e que fora formada por imigrantes trabalhadores, em sua maioria de classe baixa, vindos das mais variadas regiões do país. Economicamente muito forte, a região abriga pessoas de todas as classes sociais, mas, sobretudo, comerciantes locais e trabalhadores do Plano Piloto, os quais, num movimento similar ao das outras cidades-satélite, inundam-no durante o horário de expediente, e esvaziam-no pela noite, voltando às suas habitações.

As disparidades do contingente demográfico de ambas regiões motivaram sua escolha para análise no presente trabalho, visto que por seu contexto formador e social tão diferente e diversificado, a observação das formas eleitas pode trazer valiosa contribuição para os estudos linguísticos do falar candango, o qual, como visto, é condicionado por fatores diversos, dentre os quais destacam-se os econômicos, geracionais e interacionais. Assim, a observância deles nesses ambientes, com todas as suas particularidades, pode 
contribuir, ainda, com a sistematização desse falar - tão rico e diversificado, a despeito da proximidade geográfica.

A partir da observância desses aspectos no vernáculo, seleciona-se o fenômeno a ser estudado. Trabalha-se com a análise, coleta de dados, comparação e contextualização de formas que da língua - as variantes, observando seus aspectos semânticos, lexicais ou fonológicos. Tais formas podem ou não concorrer, a depender da análise, que pode ser feita com enfoque em um ou outro aspecto.

O presente trabalho, trata da análise de uma variável eneária, por envolver mais de duas variantes (em contraste com a binária, que observa e contrasta duas variáveis, como "nós" e "a gente", por exemplo). Observa-se as formas "tu", "você" e "cê", que concorrem em posição objetiva ou subjetiva no português brasiliense, a depender do contexto situacional, sexo, idade ou escolaridade, fatores que influenciam na produção da língua, de acordo com os estudos sociolinguísticos que, desde sua implementação, explicitam tais relações e mostram que, por exemplos, grupos econômica e intelectualmente mais privilegiados podem partilhar do uso de formas menos prestigiadas, não-padrão, a depender do contexto. Por isso, a pesquisa Variacionista preza pela análise de dados do vernáculo, em situações de fala, monitoradas ou não, objetivando encontrar quais são as relações que se estabelecem entre as diferentes dimensões envolvidas no ato de fala. 
"Todos iguais, todos iguais Mas uns mais iguais que os outros"

- Humberto Gessinger

\section{ARCABOUÇO TEÓRICO}

Esta parte do trabalho dedicar-se-á a fundamentar o presente trabalho, tendo por base as linhas teóricas correntes da Sociolinguística Variacionista, com os Elementos da Sociolinguística (3.1) na primeira parte, organizados em: (3.1.1) variação; (3.1.2) mudança; (3.1.3) norma; (3.1.4) preconceito. Ainda, contará com uma segunda parte (3.2) que fará uma revisão das literaturas, focalizando o fenômeno, com: (3.2.1) tu, você e cê na história; (3.2.2) tu, você e cê em obras tradicionais, linguísticas e sociolinguísticas; (3.2.3); e tu, você e cê no DF e arredores (3.2.4).

\subsection{ELEMENTOS DA SOCIOLINGUÍSTICA}

O que dizem as linhas teóricas correntes da Sociolinguística Variacionista tem grande valor na compreensão dos fenômenos estudados, de maneira geral. A partir da análise e compreensão desses estudos, pode-se chegar a conclusões acerca do que consiste a análise fenomenológica social, e como dão-se os processos de formação das variantes, gramaticalizações e incorporações, com suas particularidades, e qual o caminho traçado por elas até chegar ao vernáculo, levando em consideração todos os aspectos linguísticos e sociais envolvidos no ato de produção da língua, bem como da produção da linguagem. Dito isso, observaremos nas linhas subsequentes deste trabalho, quatro elementos que são de grande valia para a compreensão dos fenômenos linguísticos como um todo.

\subsubsection{VARIAÇÃO}

A variação linguística compreende os diversos movimentos e formas linguísticas que variam de acordo com o contexto interacional, contextos geográficos ou regionais ou até mesmo no contexto dos diferentes grupos ou comunidades que resguardam certas características ou "jargões" (respectivamente, variações diafásicas, diatópicas e diastráticas). Ao variarem, as línguas estabelecem, por si mesmas, as variantes, que são as formas que concorrem em uso no vernáculo - a depender dos fatores de grupo, região ou contexto supracitados; e as variáveis, que são os conjuntos de variantes que caracterizam 
determinado falar, ou língua, e podem desenvolver-se para um quadro de mudança linguística (retratada no tópico a seguir).

\subsubsection{MUDANÇA}

Mudança linguística é o resultado aferível das modificações pelas quais uma língua passa, observadas suas transformações através dos tempos ou mesmo num locus presente, atentando-se às formas escolhidas pelos falantes de uma língua, que, outrora, variaram concorrendo com outras, que tornaram-se arcaicas, caindo em desuso ou que são aferíveis em apenas alguns grupos linguísticos, podendo as mudanças estarem completadas, quando já tornaram-se características do vernáculo, da língua em si, ou em progresso, quando o processo dessa mudança ainda está em curso. Scherre (2005, p. 52) afirma que "Segundo Labov (1972), a explicação do problema da transição em uma mudança lingüística envolve a descoberta do caminho pelo qual um estágio da mudança evoluiu a partir de um estágio anterior". Não obstante, Faraco (1991, p. 13) ainda versa sobre o estudo histórico das línguas, observando-as como um fenômeno social:

O estudo científico da história das línguas tem mostrado que a implementação das inovações é feita primordialmente pelas gerações mais jovens e pelos grupos socioeconômicos ditos intermediários, classificação que costuma abranger, quando se trata de populações urbanas em sociedades industrializadas, a classe média baixa e o topo da classe operária.

Ainda, no modo de pensar de Faraco (1991; p. 20), ocorre "o processo de mudança da língua [..] desse heterogêneo quadro lingüístico, na medida em que duas ou mais variedades passam a se confrontar dialeticamente no intrincado universo das relações sócio-interacionais". Nas palavras desse mesmo pensador, tomando a Língua Portuguesa como exemplo, "embora mantenha muitas das características correntes no século XIII ou XIV, ele passou, nestes seis ou sete séculos por várias mudanças, desde a substituição lexical até alterações estilísticas, conhecendo também alterações sintáticas, sonoras e semânticas"

O fenômeno da mudança difere da variação, tornando assim, necessária atenção para o aspecto heterogêneo das diferentes comunidades de fala:

Não é qualquer diferença de fala entre gerações ou entre grupos socioeconômicos que pode estar indicando mudança. Muitas dessas diferenças são, apenas variantes características da fala de cada 
grupo e nada têm a ver, em princípio, com mudança. Daí se dizer em lingüística histórica que nem toda variação implica mudança, mas que toda mudança pressupõe variação, o que significa, em outros termos, que a língua é uma realidade heterogênea, multifacetada e que as mudanças emergem dessa heterogeneidade, embora de nem todo fato heterogêneo resulte necessariamente mudança. (FARACO, 1991).

\subsubsection{NORMA}

O termo "norma linguística" pode ser entendido como o uso comum, vernacular da língua, ou seja, é esse o termo utilizado nos estudos da língua para a designação de fatos linguísticos usuais, correntes e comuns numa determinada comunidade de fala (vd. FARACO, 2008, p. 82), ou seja, "em outras palavras, norma designa o conjunto de fatos linguísticos que caracterizam o modo como normalmente falam as pessoas de uma certa comunidade, incluindo [...] os fenômenos em variação (FARACO, 2008) ".

Mas, ainda, para se compreender o conceito de norma é válido observar outros aspectos, acepções, ou mesmo o uso do termo através dos tempos, para que consigamos ter consciência da dimensão e abrangência dele, o que expõe Marli Quadros Leite, em seu inédito texto A norma linguística: conceito e características, que diz:

Pelo que se depreende, o termo norma, tal como o usamos hoje em linguística, proveio dos sentidos atribuídos à palavra uso ao longo dos séculos. [...] A maioria das acepções da palavra uso traz a ideia do uso em geral, do hábito linguístico dos que falam a língua, de um lado, e do uso particular, o 'bom uso', de outro (LEITE, M.Q.)

Portanto, a norma linguística é um termo ambíguo em si, pois designa o que é de uso linguístico corrente numa comunidade de fala, ao passo que é utilizado também para assinalar os usos mais prestigiados da língua, sendo assim, aquilo que se tem de mais próximo de um "padrão linguístico" numa comunidade de fala. Todavia, o estudo apenas da norma não consegue abarcar a dimensão das relações sociais existentes no fato de produzir língua, pois o preconceito é, ainda, um fator de refreamento da mudança e do pleno desenvolvimento da língua, transformando-se num aspecto de grande notoriedade para os estudos linguísticos. 


\subsubsection{PRECONCEITO}

Tendo noção de que a norma linguística constitui os traços de fala apresentados por todos - ou por boa parte dos - participantes de uma comunidade de fala, ela pode servir para estigmatizar a maneira de falar daqueles que não carregam os traços mais prestigiados. Assim sendo, importa diferenciar dois grandes conjuntos de aspectos e traços linguísticos, que se diferem no prestígio perante a sociedade: os traços graduais e descontínuos.

De acordo com Bagno (2007), os traços que, de alguma forma, encaixam-se num padrão normativo, mesmo que vernacular, da língua, ou seja: "os falantes do português brasileiro que pronunciam como [o] o ditongo escrito ou, como em roupa, pouco, ouro, louco, comprou, amou [...] são, basicamente todos os falantes. A prova disso é que essa pronúncia não provoca nenhuma reação negativa". A esse grupo de traços menos estigmatizados, utilizado pela grande fatia de falantes do português, mais ou menos escolarizados, dá o se o nome de traços graduais, sendo os traços descontínuos especificamente:

[...] aqueles fenômenos lingüísticos que sofrem a maior carga de discriminação e preconceito na nossa sociedade. Por caracterizarem a variedade lingüística de falantes com baixo ou nenhum prestígio social, esses traços são rejeitados, repelidos, ridicularizados e evitados a todo custo pelos cidadãos que se acham (ilusoriamente) portadores da língua "certa" (BAGNO, 2007).

Assim, os traços descontínuos podem ser caracterizados como aqueles que sofrem maior repressão dos grupos majoritários, econômica ou socialmente, de nossa sociedade. Ou seja, o aspecto social importa no estudo das línguas, e compreender quais são os mecanismos que operam a manutenção de uma lógica excludente de língua, ajuda a esclarecer a que pé estamos em nossa estrutura orgânica língua $x$ sociedade. Portanto, uma análise da linguística como sendo a ciência que busca abolir o ensino, a gramática, ou a língua escrita, primando pelo "vale tudo", é errada, pois visam os estudos linguísticos a compreensão do ato de produzir língua, o que inclui todas as suas nuances e variáveis, como bem explicita Faraco (2008): "os lingüistas não só têm defendido que o ensino dê aos alunos acesso às variedades ditas cultas, como têm também desenvolvido uma compreensão mais refinada do próprio fenômeno dessas variedades". Assim sendo, ainda sob a égide do mesmo autor, é necessário pensar a pedagogia linguística visando o entrelaçamento do cânone normativo com as realidades sociais que cercam 0 ato de produção de língua, como pode-se depreender do excerto a seguir: 
[...] numa perspectiva pedagógica, não podemos limitar a discussão às variedades cultas em si (como apenas um conjunto de certas características léxico-gramaticais). É preciso sempre fazê-lo em conexão com as práticas socioculturais que as justificam e sustentam (FARACO, 2008, p. 169).

Adentrar o campo do preconceito linguístico é, além do ato de observar o que é estritamente estilístico e majoritário em nossa sociedade, um exercício de observação, também, das contradições existentes nas práticas pedagógicas vigentes, bem como do uso da língua, como dão a entender os quadros linguísticos mais recentes da língua portuguesa, como os feitos por Bagno em Certo ou Errado? Tanto faz! (2007) ou Perini em seu Quadro geral do Português do Brasil hoje (2011). Esses textos provocam a reflexão sobre a existência de uma norma culta falada que distancia-se das variedades linguísticas correntes de diversos grupos e falantes do português brasileiro, ao passo que distancia-se, também, da norma culta escrita, ou mesmo das recomendações normativas da gramática ${ }^{1}$, a exemplo do exposto por Faraco (2008, p. 172):

Observa-se também que a expressão culta escrita difere, em certos aspectos, da expressão culta falada. Ela é. em certo sentido, mais conservadora, embora seja cada vez mais visível a entrada na escrita de estruturas antes apenas comuns na fala culta [..] Se as variedades cultas, em suas modalidades orais e escritas, são manifestações do uso vivo (normal) da língua, a norma-padrão quando existe em determinada sociedade - é um construto idealizado (não é um "dialeto" ou um conjunto de 'dialetos', como o é a norma culta, mas uma codificação taxonômica de formas tomadas como um modelo lingüístico ideal).

Ou seja, a existência de uma norma padrão, que se distancie das outras variedades da língua, e, ainda, marginalize determinados grupos de falantes, distanciando-os da dita "boa" produção e língua portuguesa, explicita a magnitude e crueldade do preconceito linguístico, reiterando sua injustificabilidade, por ele, por si, constituir contradição e regresso no que diz respeito ao estudo e às relações da língua com a sociedade.

\footnotetext{
${ }^{1}$ Como o pronome tu que ativamente concorre nos diversos extratos linguísticos, padrão e não-padrão da língua com a forma você, que, tradicionalmente, é agramatical, constituindo um fenômeno de mudança linguística tão latente que, hoje, ocorre como um traço gradual, a despeito de sua "agramaticalidade".
} 


\subsection{REVISÃO DA LITERATURA SOBRE O FENÔMENO EM FOCO}

Esta parte do trabalho dedicar-se-á a revisar a literatura sociolinguística e canônica pertinentes ao assunto tratado na pesquisa, apresentando um panorama linguístico relacionado tanto aos processos históricos quanto aos sociais da variante observada, bem como focalizá-la perante as obras que dizem respeito ao fenômeno e aos pronomes em geral.

\subsubsection{TU, VOCÊ E CÊ NA HISTÓRIA}

As formas pronominais de segunda pessoa no português brasileiro sofreram diversas - e singulares - mudanças ao longo da história, como pode-se aferir a partir da leitura de Lopes (2008; p. 02):

A conjugação de investigações diacrônicas e sincrônicas, com base em amostras diversificadas, já nos dá alguma confiança para o estabelecimento de generalizações descritivas de sincronias pretéritas. Vosmecê, mecêa, vosse, você e a própria forma original Vossa Mercê aparentemente chegaram no Brasil sem a força cortês dos primeiros tempos - século XIII-XIV. A partir de meados do século $\mathrm{XVIII}$, os usos tornam-se divergentes. A forma vulgar você torna-se produtiva nas relações assimétricas de superior para inferior, podendo assumir, em algumas situações sócio-pragmáticas, "conteúdo negativo intrínseco", em oposição à sua contraparte desenvolvida Vossa Mercê. No Brasil, a concorrência passa a ser maior entre tu e você em relações solidárias mais íntimas a partir do século XIX. Tais valores, entretanto, permanecem disponíveis, principalmente, no português europeu em que você não se generaliza como ocorre no Brasil.

Assim sendo, entende-se que o pronome de segunda pessoa utilizado na Língua Portuguesa fora sempre o $t u$, comumente utilizado nos contextos interacionais, todavia a mutação da forma e mudança da expressão através dos tempos, culminou na atual forma você, ou contração cê, atendendo aos critérios de conveniência social que propiciam a mudança linguística, como visto nos itens anteriores que falam sobre a variação e mudança linguística.

Ainda, dentro do campo das mudanças que propiciaram a mutação da forma através dos tempos, percebe-se "que a cadeia não fecha com a redução de vossa mercê para você. Ela continua e pode acabar, daqui a algum tempo, no cê, monossílabo, como a 
maioria dos pronomes pessoais" (SILVA, 2009). Ainda, apoiando-se nos estudos de Silva, em A Sociolinguística e a Língua Materna, pode-se compreender o quadro dos processos que culminaram nas características pronominais de segunda pessoa no português brasileiro (aspecto abordado ainda neste capítulo).

Assim sendo, pela organicidade da língua pode-se inferir que a mudança desse pronome ainda não está completada, bem como, ainda pela mesma característica linguística, compreender os processos que propiciaram a existência das formas em ocorrência e concorrência neste trabalho estudadas. Entretanto, como tangenciado anteriormente, ainda não há um consenso acerca do uso da forma você (tampouco da contração cê que, apesar de popular, ainda carrega estigmas) na gramática normativa. Assunto abordado no próximo tópico.

\subsubsection{TU E VOCÊ EM OBRAS TRADICIONAIS, LINGUÍSTICAS E SOCIOLINGUÍSTICAS}

Para o levantamento de dados respectivos à literatura tradicional que trata dos pronomes, três gramáticas formas escolhidas: a "Breve Gramática do Português Contemporâneo", de Celso Cunha e Lindley Cintra; a "Moderna Gramática Portuguesa", de Evanildo Bechara; e a "Gramática Normativa da Língua Portuguesa", de Rocha Lima. A escolha dessas obras tradicionais da língua portuguesa, deu-se por sua relevância e peso nos estudos normativos da língua portuguesa no Brasil, e servem, tais obras, como parâmetro de contraste entre os textos canônicos tradicionais, que primam pela normatização da língua, e os sociolinguísticos, que primam pelo tratamento do vernáculo de acordo com o uso e contínuo desenvolvimento dela.

A análise da "Breve Gramática do Português Contemporâneo" revelou que esta vê apenas o "tu" como pronome pessoal reto de segunda pessoa do singular, com "te" átono, e "ti" e "contigo" tônicos, sem fazer menção à existência de formas concorrentes. Vale ressaltar que, ao normatizar a ocorrência de pronomes sujeitos, utiliza esta gramática do exemplo "Vocês é que morrem, meu alferes, mas nós é que pagamos" (p. 208), valendo-se desse, um excerto literário de Luandino Vieira, para ressaltar a expressão invariável "é que". Ou seja, na categoria do plural da segunda pessoa, admite esta gramática a existência do pronome "vocês", a despeito de menção alguma fazer anteriormente, valendo-se, para normatizar este número e pessoa pronominal, da forma "vós", exclusivamente.

A "Moderna Gramática Portuguesa", trata os pronomes pessoais como aqueles que "designam as duas pessoas do discurso e a não pessoa (não eu, não tu), considerada, pela tradição, a 3. ${ }^{a}$ pessoa" (p. 139), considerando a "2. a pessoa: tu (singular), vós (plural)" dos 
prnomes pessoais retos, e, ainda, as formas te e ti, como pronomes pessoais oblíquos singulares, e vos e vós, como pronomes pessoais oblíquos do plural. Tal gramática não trata ou menciona outros tipos de pronomes que possam concorrer ou coocorrer às formas supracitadas, encerrando a explanação acerca considerando, de fato, apenas esses como pronomes pessoais.

Já a "Gramática Normativa da Língua Portuguesa", de Rocha Lima, ao conceituar os pronomes pessoais declara:

Pronomes pessoais são palavras que representam as três pessoas do discurso, indicando-as simplesmente, sem nomeá-las. A primeira pessoa, aquela que fala, chama-se eu, com o plural nós-, a segunda, tu, que é a com que se fala, com o plural vós-, a terceira, que é a pessoa ou coisa de que se fala, é ele ou ela, com os plurais respectivos eles ou elas. (ROCHA LIMA, 2011, p. 156)

Não trata, portanto, num primeiro momento, qualquer outra forma, senão a tu para com quem se fala no singular e vós no plural, como um pronome pessoal. Ainda, a mesma gramática trata a segunda pessoa pronominal oblíqua como as formas te (átona), ti (tônica), vos (átona) e vós (tônica). Entretanto, vale destacar que Rocha Lima registra as formas você e vocês (p. 158) como "pronomes de segunda pessoa que requerem para o verbo as terminações de terceira", classificando-as como formas de "tratamento familiar".

Assim sendo, depreende-se que, de acordo com os textos canônicos escolhidos para a representação da corrente gramatical tradicional, o uso das formas tu, você e cê pode ser visto como agramatical, por não haver sua menção na conceituação de pronome, ou, como pôde-se observar, como uma "forma familiar", espécie de sublinha, desprezando as escolhas linguísticas relacionadas ao uso das formas estudadas nesse trabalho, como poderá ser visto a seguir.

Lopes (2008) afirma que "levando-se em consideração os fluxos e contrafluxos da variação você/tu no século $X X$, alguns estudos demonstraram que o uso majoritário de tu forma recorrente no século XIX - só será suplantado por você por volta dos anos 20-30 do século XX". Portanto, como pôde-se depreender de tal excerto, que muito fala sobre a realidade linguística do Brasil hoje, que o processo evolucional da língua, dá-se de forma assimétrica, influenciado pelos vários aspectos que perpassam as relações sociais, e que possibilitam, a ora ou outra, a incorporação de formas, outrora arcaizadas ou estigmatizadas, por diferentes grupos de falantes, constituindo variáveis que, com o desenvolvimento e movimento sociais, culminam em variantes como a nesse parágrafo exposta, assim ocorrendo nas diversas dimensões e casos da história das línguas. 
Entretanto, faz-se, ainda, necessário compreender o motivo das formas concorrentes do tu ocorrerem de maneira tão contundente, sendo amplamente difundidas no português do Brasil. Os estudos de Penkal (2004) dão a entender de que forma deu-se o encadeamento de uso e assimilação do você no contexto de nossa língua:

A respeito da generalização do uso de você no Brasil, CINTRA (1972); BIDERMAN (1972/73); FARACO $(1992,1996)$ e MENON (1995) destacam que quando o Brasil começou a ser colonizado, em Portugal já estava avançado o processo de arcaização do vós que se tornou, já no século XVIII, completamente arcaico, assim como a mudança fonética de Vossa Mercê, que na época já era utilizado em Portugal entre os não-nobres. MENON (1995:95) destaca também que houve a introdução do par você/vocês no paradigma da segunda pessoa e, com isso, as novas formas passam a coocorrer e concorrer com a antiga oposição tu/vós, suplantando primeiro a forma vós, que se tornou arcaica. Dessa forma, travou-se uma "batalha" em que vocês se torna a forma vencedora e passa a ser o plural tanto de tu quanto de você. (PENKAL, 2004, p 44).

\subsubsection{TU, VOCÊ E CÊ NO DF E ARREDORES}

O trabalho Tu, Você, Cê e Ocê na variedade brasiliense, de Andrade, Scherre, Dias, Lucca e Andrade (2011), versa sobre a situação da variação dos pronomes de segunda pessoa do singular no Distrito Federal, apresentando breve panorama sobre a literatura atual que fala do português candango, encaixando as formas nesse trabalho focalizadas na comunidade de fala brasiliense, esclarecendo que:

[...] nas amostras brasilienses colhidas em 2004-2005 (Lucca, 2005); 2006-2007 (Dias, 2007); e 2008-2009 (Andrade, 2010), observou-se que os pronomes tu, você, cê se alternam em enunciados de pequena extensão, embora já se saiba ser comum a ocorrência de blocos de um mesmo pronome, analisados pela variável paralelismo linguístico em diversas pesquisas. [...] No início da década de 2000, todavia, já era fácil perceber o pronome tu na fala brasiliense, especialmente na de jovens do sexo masculino em conversas espontâneas entre si. (SCHERRE; DIAS; ANDRADE; LUCCA; ANDRADE, 2011, p. 3)

Em outras palavras, é possível, pelas pesquisas atuais, perceber no DF a presença de certos padrões de uso pronominais, os quais seguem, a certo nível, a lógica de 
desenvolvimento de uso de formas pronominais aferido por todo o país, a despeito da juventude da nova capital - e, talvez, influenciado pelo grande fluxo migratório ocorrido durante a "marcha para o Centro-Oeste" dos anos 60 e 70, como explica, ainda, o mesmo estudo:

Deste breve panorama das quatro pesquisas envolvidas nos pronomes de segunda pessoa na fala brasiliense, podemos identificar: (1) um jogo temporal, em um intervalo aproximado de uma geração (18 anos), de 1991 a 2009, registrando-se o processo de focalização do pronome tu, ocupando espaços do pronome você: embora não haja pesquisas com amostras de Sobradinho na década de 2000, há depoimentos de que o pronome tu é usado lá nos dias atuais; (2) um jogo etário e geracional, com o pronome tu predominando nos dados dos falantes e das falantes mais jovens; (3) um jogo geográfico, com o pronome tu predominando em áreas com maior concentração de migrantes da região Nordeste; (4) um jogo de gênero e de interação, com o tu predominando nas falas masculinas e em práticas discursivas entre pares solidários, na mesma linha do que se observa no Rio de Janeiro (Paredes Silva, 2003; Lopes et alii, 2009), mas diferente do que ocorre no Rio Grande do Sul, onde o tu sem concordância - forma espontânea e natural - é mais favorecido pelas mulheres (LOREGIAN-PENKAL, 2004: 135-137).

Portanto, de acordo com tais recentes estudos do português brasiliense, depreende-se que:

[...] a fala brasiliense sintetiza grande parte do Brasil: adota variavelmente um tu supra-regional sem concordância, que se espraia para domínios sociais e discursivos mais amplos, como traço local; retém os pronomes você e cê, em taxas variadas; mas não fixa o pronome ocê, também marcado, do Brasil central de Goiás e de Minas Gerais, com mais vigor em áreas rurais. O tu brasiliense - sem concordância - se revela como um traço de focalização dialetal, de identidade da fala brasiliense em formação.

Assim, pode-se concluir que os pronomes tratados nesse trabalho, além de carregarem, em si, traço de mudança histórica no português, podem ser percebidos como processos naturais de evolução da língua falada no Distrito Federal, o que diz respeito às escolhas linguísticas dessa comunidade de fala, o que chama atenção para o subsídio identitário da língua falada no DF, bem como evidencia o reflexo histórico que têm essas escolhas no contexto social interacional da comunidade candanga. 
"Pois que não existe a língua das línguas Não existe certeza firme, pura

Talvez reza que diz que curte, cura E as estrelas querem mesmo é dançar" - Murilo Vieira Komnisky

\section{ANÁLISE DOS DADOS}

Nesta parte do trabalho, será feita a análise dos dados coletados, com base na metodologia e pressupostos teóricos já expostos, à luz da Teoria laboviana da Variação. Em 4.1, serão vistos os elementos que condicionam o fenômeno no corpus analisado, dividindose nos subitens: 4.1.1, que tratará das variáveis sociais analisadas neste trabalho, levando este aspecto em consideração para a produção dos períodos de fala coletados; e 4.1.2, que tratará das variáveis linguísticas relacionadas à produção e utilização das formas tu, você e cê nos discursos coletados que compõem o corpus do presente estudo.

\subsection{ELEMENTOS CONDICIONANTES DO FENÔMENO}

A sociolinguística é o estudo das relações entre a língua e a sociedade, seus processos de desenvolvimento e mudança através dos tempos, que ocorre indivisivelmente entre esses dois fatores. Sendo assim, o contexto linguístico de uma sociedade apenas pode ser descrito se levados em consideração os elementos que propiciam a variação e mudança da língua através dos tempos. Portanto, nessa parte do trabalho, serão expostos fatores condicionantes da variação do português brasiliense falado, que darão subsídio para a compreensão dos processos de mudança linguística que têm culminado na alternância das formas tu, você e cê em duas regiões (Taguatinga e Brasília) do Distrito Federal.

\subsubsection{VARIÁVEIS SOCIAIS}

O estudo das variáveis sociais é preponderante nos estudos sociolinguísticos, pois apenas a partir de sua junção com as variáveis linguísticas pode-se postular as teorias relacionadas à produção de fala e ao patamar de escolha linguísticas dos falantes, bem como a variação e mudança das formas na língua. As variáveis sociais caminham junto das linguísticas na oblíqua, porém sistemática engrenagem da evolução da língua. 


\section{. a) Localidade}

A localidade é de suma importância para a compreensão das escolhas que cada um dos grupos tem tomado em relação à produção de língua. Importa compreender como falam os participantes dos grupos linguísticos das localidades focalizadas, para que se possa comparar os dados obtidos visando o estabelecimento de diferenças entre os grupos, ou, nesse caso, de uma confluência de escolhas de utilização dessas formas, o que pode configurar um indício de mudança em curso, que é o caminho natural para o estabelecimento de características próprias do falar candango - ainda em estabilização, por conta, também, do contexto de formação da nova capital. O aspecto socioeconômico, como já tangenciado, influencia sumariamente nesse aspecto, pois o contexto de formação social e econômico das duas regiões analisadas oferece subsídio para que se possa compreender quem e o que está propiciando a utilização de uma outra forma, e o porquê da estigmatização dela.

Cada uma das localidades focalizadas tem um processo específico de formação, com pessoas de maior (no caso de Brasília) ou menor (que é o caso de Taguatinga) nível socioeconômico e prestígio social, além da escolarização. Assim, sendo, é possível - e os dados a seguir evidenciarão isso - que a escolha das formas seja condicionada ao grau de escolarização e nível interacional dos falantes, o que pode levar à escolha de uma forma em detrimento de outra, pelo fato da estigmatização de uma, ou pelo frequente uso de formas mais prestigiadas nos contextos comunicativos dos falantes.

As regiões de Brasília e Taguatinga, além de possuírem um elevado número de moradores, são econômica e socialmente muito importantes para o Distrito Federal, contribuindo ativamente para o desenvolvimento dessa região do Brasil, e funcionando como polos econômicos e laborativos, recebendo diversas pessoas, e, consequentemente falantes, das mais variadas regiões do DF. Portanto, compreender como a língua tem sido utilizada em cada uma dessas localidades, é, além de estudar a linguagem por si, compreender a identidade do povo brasiliense.

No intuito de caracterizar ambas as regiões focalizadas, as tabelas a seguir (Tabela 1 e Tabela 2) oferecem um inicial panorama do patamar de utilização das formas tu, você e cê nas áreas em destaque. É válido ressaltar que nestas tabelas, bem como nas outras constantes nesta pesquisa, mantendo o paralelismo de códigos, (P) refere-se a "participante"; a coluna "Total" diz respeito a todas as ocorrências das formas, de acordo com o enfoque, seja social ou linguístico, do quadro; e que números totais, bem como períodos de exemplificação, com asterisco $\left({ }^{*}\right)$ incluem em sua soma, ou dizem respeito a discurso reportado: 


\begin{tabular}{|c|c|c|c|c|c|c|}
\hline \multicolumn{7}{|c|}{ Plano Piloto } \\
\hline \multirow[t]{2}{*}{ Variantes } & \multicolumn{5}{|c|}{ Ocorrências } & \multirow[b]{2}{*}{ Total } \\
\hline & P1 & P2 & P3 & P4 & P5 & \\
\hline TU & $\begin{array}{l}\text { "fala aí, TU **** } \\
\text { quem?" }\end{array}$ & & & & & $2^{*}$ \\
\hline VOCÊ & $\begin{array}{l}\text { não, calma, eu } \\
\text { vou explicar pra } \\
\text { VOCÊ }\end{array}$ & $\begin{array}{l}\text { parece que } \\
\text { VOCÊ tá sendo } \\
\text { uma pessoa } \\
\text { lerda quando } \\
\text { VOCÊ fala ideia }\end{array}$ & $\begin{array}{l}\text { de acordo com a } \\
\text { gramática se } \\
\text { vOCÊ for ler não } \\
\text { é com 'i' }\end{array}$ & $\begin{array}{l}\text { porque aí VOCÊ } \\
\text { consegue } \\
\text { trabalhar num } \\
\text { âmbito político } \\
\text { dentro das } \\
\text { prefeituras }\end{array}$ & $\begin{array}{l}\text { porque aí VOCÊ } \\
\text { consegue trabalhar } \\
\text { num âmbito } \\
\text { político dentro das } \\
\text { prefeituras }\end{array}$ & 22 \\
\hline$C \hat{E}$ & $\begin{array}{l}\text { ah, tipo, CÊ tá } \\
\text { muito coisado }\end{array}$ & $\begin{array}{l}\text { CÊ pode falar } \\
\text { que é moleque } \\
\text { banda. Pronto! }\end{array}$ & $\begin{array}{l}\text { é difícil CÊ ver } \\
\text { avô assim }\end{array}$ & & & 23 \\
\hline
\end{tabular}

[Tabela 1: Ocorrência das formas T,V,C no Plano Piloto e adjacências]

\begin{tabular}{|c|c|c|c|c|c|}
\hline \multicolumn{6}{|c|}{ Taguatinga } \\
\hline Variantes & \multicolumn{4}{|c|}{ Ocorrências } & \multirow[b]{2}{*}{ Total } \\
\hline & P1 & P2 & P3 & P4 & \\
\hline TU & $\begin{array}{l}\text { Fiquei feliz } \\
\text { que TU saiu } \\
\text { daquele } \\
\text { lugar, na } \\
\text { moral }\end{array}$ & $\begin{array}{l}\text { "Ba, guria, } \\
\text { não, mas TU } \\
\text { fala muito } \\
\text { diferente da } \\
\text { gente }\end{array}$ & & & $4^{*}$ \\
\hline & $\begin{array}{l}\text { [...] Só que } \\
\text { aí VOCÊ tem } \\
\text { vários } \\
\text { bares, aí } \\
\text { VOCÊ pode } \\
\text { escolher } \\
\text { qual bar } \\
\text { VOCÊ quer } \\
\text { ir }\end{array}$ & $\begin{array}{l}\text { Eu acho que } \\
\text { padrão é } \\
\text { onde VOCÊ } \\
\text { tá }\end{array}$ & $\begin{array}{l}\text { [...] VOCÊ } \\
\text { mesmo não } \\
\text { conhecendo } \\
\text { a pessoa, só } \\
\text { pela fala } \\
\text { dela, VOCÊ } \\
\text { percebe que } \\
\text { ela é } \\
\text { daquele } \\
\text { local }\end{array}$ & $\begin{array}{l}\text { acho que é } \\
\text { importante } \\
\text { porque } \\
\text { VOCÊ } \\
\text { começa a } \\
\text { entender o } \\
\text { que é falado } \\
\text { aqui }\end{array}$ & 23 \\
\hline \multicolumn{6}{|l|}{ VOCÊ } \\
\hline$C \hat{E}$ & & $\begin{array}{l}\text { Na } \\
\text { Ceilândia, } \\
\text { CÊ vê muito } \\
\text { mais } \\
\text { nordestinos } \\
\text { do que aqui }\end{array}$ & & $\begin{array}{l}\text { ajudo pô. O } \\
\text { que que CÊ } \\
\text { precisa? }\end{array}$ & 8 \\
\hline
\end{tabular}

[Tabela 2: Ocorrência das formas tu, você e cê na região de Taguatinga e adjacências] 


\section{b) Sexo/Gênero}

A variável sexo, usualmente utilizada no estudo dos usos de formas linguísticas em geral, por constituir, em muito dos estudos, importantes paradigmas para a compreensão do fenômeno estudado, fora escolhida para que o presente trabalho pudesse ter uma noção geral do quadro pronominal no português brasiliense. Como postulado por Weinreich, Labov e Herzog (2006 [1968]), no livro Fundamentos empíricos para uma teoria da mudança linguística, há uma proposta de que ao lado dos fatores internos à língua, caminham os externos, que são de preponderantes para a compreensão dos fenômenos de variação, afirmando, até, que alguns deles podem ser responsáveis pelas mudanças na língua. Ainda, no que se refere às ideias desse mesmo autor, e, inclusive, embasando-se nele, Scherre e Yacovenco (2011) sintetizam a importância do estudo desse aspecto na produção de língua:

Assim, a classe social, o sexo do falante e a sua faixa etária, por exemplo, são variáveis recorrentes na análise e interpretação dos fenômenos linguísticos variáveis. [...]Labov (1990; 2001) dá continuidade à efervescente discussão sobre o papel do gênero em fenômenos linguísticos variáveis e assume uma codificação necessária em função do sexo do falante, abordagem biológica, para permitir comparabilidade entre as pesquisas, e interpretação em função do gênero, abordagem sócio-cultural. Observa que o efeito do gênero apresenta diferenças instigantes, conforme o tipo de mudança [...], ao lado do comportamento conservador na variação estável: em mudanças com consciência social (changes from above). (SCHERRE; YACOVENCO, 2011, p. 1).

A despeito dos trabalhos de Lucca (2005) mostrarem uma proporção de 0,55\% de ocorrência do pronome tu em relação a uma taxa de utilização de 0,09\% de ocorrência do mesmo pronome na fala das mulheres de Brasília, os dados atuais apontam para uma influência baixa do fator sexo na produção de períodos que contenham pronomes de segunda pessoa. O que parece haver, observando os dados coletados nesse estudo, e ambientes de ocorrência das formas e estudos relacionados ao português brasiliense, é uma progressiva tendência de apagamento da forma $t u$, estigmatizada por grupos mais abastados e apenas não ocorrente em grupos menos privilegiados economicamente, em detrimento das formas você e cê, que fortemente concorrem em ocorrência, sobretudo entre os mais jovens. A exemplo de Modesto (2009) que julgou irrelevante o fator gênero em sua pesquisa linguística dos pronomes em Santos (SP), nessa ele mostrou-se importante para a compreensão da taxa de ocorrência, e tendência de "pareamento" de uso das formas pronominais, movimento progressivamente documentado nos mais recentes estudos do 
fenômeno no Distrito Federal. No sentido de explicitar a preferência de utilização das formas pronominais de segunda pessoa no português falado no Distrito Federal, o quadro abaixo quantifica, dentre o corpus recolhido e analisado neste trabalho, as ocorrências dividas de acordo com a variável social sexo:

\begin{tabular}{|c|c|c|c|}
\cline { 2 - 4 } \multicolumn{1}{c|}{} & \multicolumn{2}{c|}{$\begin{array}{c}\text { Número de uso das formas } \\
\text { pronominais }\end{array}$} & \multirow{2}{*}{ Total } \\
\cline { 2 - 3 } \multicolumn{1}{c|}{} & Homens & Mulheres & \\
\hline TU & 3 & 2 & 5 \\
\hline VOCÊ & 24 & 21 & 45 \\
\hline CE & 17 & 13 & 30 \\
\hline
\end{tabular}

[Tabela 3: Número de uso das formas pronominais tu, você e cê, por homens e mulheres]

\subsubsection{VARIÁVEIS LINGUÍSTICAS}

Importa falar sobre as variáveis linguísticas no que diz respeito a qual tipo de ambiente favorece a proliferação das formas estudadas, qual sua função ou o tipo de sentença na qual ocorrem. Sendo assim, as variáveis linguísticas observadas e analisadas no presente trabalho - que são posição sintática, tipo de construção que o fenômeno aparece, e o tipo de discurso, são estritamente sintáticas, não adentrando os campos da fonética e fonologia, pois o objetivo da observância de tais aspectos é a constituição de um panorama linguístico do falar candango atual, observando as mudanças ocorridas no plano sintático que justifiquem as escolhas linguísticas feitas pelos falantes da variedade brasiliense do português.

\section{a) Posição Sintática}

Importa compreender em qual posição sintática ocorrem os pronomes destacados, para que se possa constituir um quadro o mais fidedigno possível das situações de uso dessa variável. A posição, objetiva ou subjetiva, do fenômeno mostra como se dá o processo ide formação das sentenças, tendo o enfoque no aspecto interacional. A ocorrência de uma ou outra forma em cada uma das posições sintáticas supracitadas, pode evidenciar padrões linguísticos que ajudam a compreender qual o fator condicionante, 
observado, principalmente o contexto interacional entre os falantes, de produção dos termos em foco.

A posição subjetiva (+SB) ou não-subjetiva (-SB), como exposto na tabela abaixo, será um aspecto observado para que possamos compreender a tendência de utilização dos pronomes de segunda pessoa nas orações dos falantes pesquisados. É válido ressaltar que as entrevistas foram todas feitas com conhecimento do participante da pesquisa sobre gravação de áudio, e isso pode implicar em discursos menos fidedignos aos de contextos de fala onde há um maior nível de proximidade entre os falantes, ou mesmo de contextos menos monitorados de fala, sendo este último, importante aspecto, observado no tópico que tratará do tipo de discurso empregado pelo falante no momento da coleta dos dados.

$\mathrm{Na}$ tabela abaixo, pode-se perceber o número de uso das formas em posição subjetiva (+SB) e não-subjetiva (-SB), dividido pela variável sexo:

\begin{tabular}{|c|c|c|c|}
\hline $\begin{array}{c}\text { Posição } \\
\text { Sintática }\end{array}$ & HOMEM & MULHER & Total \\
\hline +SB & 28 & 21 & 49 \\
\hline -SB & 0 & 4 & 4 \\
\hline \multicolumn{2}{r|}{ [Tabela 4: número de uso das formas em posição subjetiva ou não-subjetiva] }
\end{tabular}

\section{. b) Tipo de Construção/Estrutura}

A construção do período que engloba os pronomes em questão é importante para que se compreenda as minúcias relacionadas às sentenças nas quais o fenômeno se manifesta. O paralelismo na ocorrência de uma ou outra forma, por exemplo, é uma forma de aferir as tendências de ocorrência ou apagamento dela, pois, se levada em consideração a proeminência do tipo de sentença relacionado à produção dessa forma, pode-se chegar a um retrato mais claro dos fatores que propiciam seu uso, ou mesmo quais os fatores extralinguísticos que estão imbricados nele, como é o caso da autocorreção, ou da escolha de uso de uma forma pronominal mais privilegiada.

Como a tabela abaixo indica, o paralelismo na utilização entre as formas pode ser tido como uma relevante variável linguística, visto que o corpus colhido apresenta padrões estruturais de ocorrência, o que evidencia as preferências estruturais no que diz respeito à utilização pronominal dos falantes do português brasiliense: 


\begin{tabular}{|c|c|c|c|}
\hline \multirow{2}{*}{ Variantes } & \multicolumn{2}{|c|}{ Exemplos } & \multirow{2}{*}{ Total } \\
\hline & HOMEM & MULHER & \\
\hline TU & & & 0 \\
\hline VOCÊ & $\begin{array}{l}{[\ldots] \text { VOCÊ }} \\
\text { está, e o } \\
\text { que VOCÊ } \\
\text { vai falar? }\end{array}$ & $\begin{array}{l}\text { parece que } \\
\text { VOCÊ tá } \\
\text { sendo [..] } \\
\text { VOCÊ fala } \\
\text { ideia }\end{array}$ & 8 \\
\hline CÊ & $\begin{array}{l}\text { aqui CÊ não } \\
\text { tem sota- } \\
\text { que, CÊ vai } \\
\text { no Rio }[\ldots]\end{array}$ & $\begin{array}{l}\text { mas aí CÊ } \\
\text { fala: } C \hat{E} \text { vai } \\
\text { cair de boca } \\
\text { na comida }\end{array}$ & 4 \\
\hline $\begin{array}{c}\text { VOCÊ - } \\
\text { CÊ }\end{array}$ & $\begin{array}{l}\text { e VOCÊ [...], } \\
\text { CÊ acha que } \\
\text { o mundo tá } \\
\text { mais nessa } \\
\text { tendência? }\end{array}$ & $\begin{array}{l}\text { Se VOCÊ } \\
\text { quiser [..], } \\
\text { CÊ vai ter } \\
\text { que pegar } \\
\text { um ônibus }\end{array}$ & 3 \\
\hline $\begin{array}{c}\text { CÊ - } \\
\text { VOCÊ }\end{array}$ & $\begin{array}{l}{[\ldots] \text { CÊ acha }} \\
\text { que como é } \\
\text { que tá? [...] } \\
\text { ou VOCÊ } \\
\text { acha que } \\
\text { não? [...] }\end{array}$ & $\begin{array}{l}\text { Mas aí } \\
\text { quando CÊ } \\
\text { começa a } \\
\text { falar.. Ah, } \\
\text { VOCÊ não é } \\
\text { daqui }\end{array}$ & 3 \\
\hline
\end{tabular}

[Tabela 5: número de ocorrências de sentenças que mantém paralelismo no uso das formas pronominais tu, você e cê]

Ainda, pode-se observar, nas tabelas 6, 7 e 8, a preferência de utilização das formas nos diferentes tipos de estrutura em que ocorrem no corpus colhido. As estruturas Exclamativas (EX), Explicativas (EP), Interrogativas (IN) e Afirmativas (AF) foram as escolhidas pelos falantes quando utilizados os pronomes de segunda pessoa do singular, e assim distribuíram-se:

\begin{tabular}{|c|c|c|c|c|}
\cline { 2 - 5 } \multicolumn{1}{c|}{} & \multicolumn{2}{|c|}{ Púmero de uso das formas pronominais } & \multicolumn{2}{c|}{ Total } \\
\cline { 2 - 5 } & EX & $\begin{array}{c}\text { a gente fala com uma pessoa de outro estado, e eles ficam falando } \\
\text { "meu Deus, voCÊs falam muito errado!" }\end{array}$ & 1 & 0 \\
\hline EP & não, aí VoCÊ vai falar, já vira boy, mina & $\begin{array}{c}\text { [..] por exemplo se VOCÊ for na } \\
\text { feira da Ceilândia }\end{array}$ & 10 \\
\hline IN & ah, tipo, CÊ tá ligada? & $\begin{array}{c}\text { Agora quando VOCÊ fala um } \\
\text { "tarra" aqui, é nossa! De que } \\
\text { mundo VoCÊ é? }\end{array}$ & 10 \\
\hline AF & não, mas CÊ ficou feia, né & $\begin{array}{c}\text { Fiquei feliz que TU saiu daquele } \\
\text { lugar, na moral }\end{array}$ & 12 \\
\hline
\end{tabular}

[Tabela 6: Número dos períodos nos quais as construções com os pronomes estudados ocorrem] 


\begin{tabular}{|c|c|c|c|c|}
\hline & \multicolumn{3}{|c|}{ Uso das formas pronominais } & \multirow{2}{*}{ Total } \\
\hline & TU & VOCE & $\hat{\mathbf{C E}}$ & \\
\hline EX & & $\begin{array}{l}\text { a gente fala com uma pessoa de } \\
\text { outro estado, e eles ficam falando } \\
\text { "meu Deus, VOCÊs falam muito } \\
\text { errado!" }\end{array}$ & & 1 \\
\hline EP & $\begin{array}{c}\text { [..] e aí TU usa o controle pra } \\
\text { digitar o que quiser }\end{array}$ & $\begin{array}{c}\text { não, calma, eu vou explicar pra } \\
\text { VOCÊ }\end{array}$ & $\begin{array}{c}\text { CÊ tá tipo, CÊ passa a } \\
\text { vida toda, assim, } \\
\text { morando em Brasília }\end{array}$ & 16 \\
\hline IN & 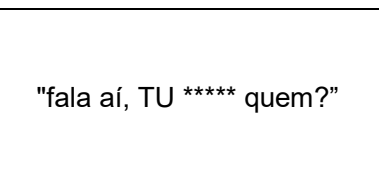 & [...] De que mundo VOCÊ é? & $\begin{array}{l}\text { CÊ acha que a } \\
\text { globalização tá } \\
\text { acabando com os } \\
\text { sotaques? }\end{array}$ & 13 \\
\hline AF & $\begin{array}{l}\text { Eu acho que TU vai curtir pra } \\
\text { caramba o controlezinho [...] }\end{array}$ & $\begin{array}{l}\text { o que vai te deixar na frente são } \\
\text { esses estudos a mais que VOCÊ } \\
\text { faz }\end{array}$ & $\begin{array}{l}{[\ldots] \text { CÊ vai ter que }} \\
\text { pegar um ônibus }\end{array}$ & 30 \\
\hline
\end{tabular}

[Tabela 7: Tipos de construções nas quais os pronomes estudados ocorrem]

\begin{tabular}{|c|c|c|c|c|c|c|}
\hline $\begin{array}{l}\text { Tipo de } \\
\text { sentença }\end{array}$ & & Total & & Total & & Total \\
\hline EX & ext & 0 & exv & 1 & exc & 0 \\
\hline EP & ept & 1 & epv & 10 & epc & 4 \\
\hline IN & int & 1 & inv & 4 & inc & 8 \\
\hline$A F$ & aft & 3 & afv & 16 & afc & 11 \\
\hline
\end{tabular}

[Tabela 8: Número de ocorrências das formas tu, você e cê nos tipos de construção analisados]

\section{.c) Tipo de Discurso}

O tipo de discurso ajuda a compreender o patamar de estigmatização de uma forma, bem como o tipo de contexto interacional no qual as variantes mais ocorrem. Situações de discurso reportado, ou de monitoramento de fala, por exemplo, podem demonstrar o quanto o uso de uma forma está condicionado ao tipo de mensagem que se quer passar, ou o nível de proximidade entre os falantes, bem como os traços identitários identificáveis pela escolha das variáveis. Ou seja, a maneira como o discurso é produzido ajuda a compreender quais são os aspectos subjetivos de identidade e intencionalidade presentes nas falas entre os pares linguísticos, evidenciando as escolhas dos falantes ao transmitirem uma mensagem. 
Os pronomes utilizados pelos participantes da pesquisa, nos diferentes tipos de discurso, serviram, também de grande fonte de elucidação no que diz respeito às suas preferências discursivas, sejam elas Gerais, Diretas ou Indiretas, e demonstram como o monitoramento de fala e as escolhas de interlocução se dão nos contextos de língua falada, ao contar histórias, referir-se a outros interlocutores ou mesmo reportar discursos. Nesse sentido, as próximas tabelas (9 e 10), demonstram as preferências de utilização discursivas por parte dos informantes participantes da pesquisa, levando em consideração os tipos de interlocução utilizados, e os pronomes escolhidos em cada um dos tipos de construção. Vale ressaltar que as entrevistas, ao serem feitas com conhecimento da gravação por parte dos participantes, e por não haver grau de parentesco ou proximidade do entrevistador com eles, podem não evidenciar como se dão as utilizações das formas estudadas em contextos não monitorados ou estritamente informais de fala, sendo necessários estudos com gravações ocultas para o exame fidedigno desses aspectos menos formais de interlocução.

\begin{tabular}{|c|c|c|c|c|c|c|c|}
\hline \multirow{2}{*}{$\begin{array}{c}\text { Tipo de } \\
\text { interlocução }\end{array}$} & \multicolumn{7}{|c|}{ Formas Utilizadas } \\
\hline & TU & Total & VOCÊ & Total & CÊ & Total & Total Geral \\
\hline Indireta & $\begin{array}{l}\text { [..] mas TU } \\
\text { fala muito } \\
\text { diferente da } \\
\text { gente!" }\end{array}$ & 2 & $\begin{array}{l}\text { aí elas "nossa, } \\
\text { VOCÊs falam } \\
\text { engraçado" }\end{array}$ & 10 & $\begin{array}{c}\text { Calma gente, } \\
\text { eu sei que CÊs } \\
\text { não } \\
\text { entenderam } \\
\text { nada do que } \\
\text { ela falou }\end{array}$ & 5 & 17 \\
\hline Direta & $\begin{array}{c}\text { Fiquei feliz } \\
\text { que TU saiu } \\
\text { daquele } \\
\text { lugar, na } \\
\text { moral }\end{array}$ & 2 & $\begin{array}{c}\text { e VOCÊ como } \\
\text { sociolinguis-ta } \\
\text { [?] }\end{array}$ & 5 & $\begin{array}{c}\text { CÊs estudam } \\
\text { sonoridade } \\
\text { também, né? }\end{array}$ & 10 & 17 \\
\hline Geral & $\begin{array}{c}\text { [...] e aí TU } \\
\text { usa o } \\
\text { controle pra } \\
\text { digitar o que } \\
\text { quiser }\end{array}$ & 1 & \begin{tabular}{|c} 
VOCÊ fica, \\
praticamen- \\
te, no 3o ano, \\
estagnado
\end{tabular} & 17 & $\begin{array}{c}\text { CÊ precisa ter } \\
\text { um padrão } \\
\text { pra que seja } \\
\text { compreendi- } \\
\text { do por todo } \\
\text { mundo }\end{array}$ & 8 & 25 \\
\hline
\end{tabular}

[Tabela 9: Tipos de discurso nos quais as formas tu, você e cê ocorrem] 


\begin{tabular}{|c|c|c|c|c|c|c|c|}
\hline \multirow{3}{*}{$\begin{array}{l}\text { Tipo de } \\
\text { interlocução }\end{array}$} & \multicolumn{7}{|c|}{ Formas utilizadas } \\
\hline & \multicolumn{2}{|l|}{ TU } & \multicolumn{2}{|l|}{ VOCÊ } & \multicolumn{2}{|l|}{ ChE } & \multirow{2}{*}{ Total Geral } \\
\hline & Taguatinga & P. Piloto & Taguatinga & P. Piloto & Taguatinga & P. Piloto & \\
\hline Indireta & 1* & 1* & 5 & 5 & 1 & 4 & 17 \\
\hline Direta & 2 & 0 & 2 & 3 & 4 & 6 & 17 \\
\hline Geral & 1 & 0 & 8 & 8 & 3 & 5 & 25 \\
\hline
\end{tabular}

[Tabela 10: Tipos de discurso nos quais as formas tu, você e cê ocorrem, divididos por Região]

\subsubsection{CRUZAMENTO DAS VARIÁVEIS}

Em relação aos dados coletados, há peculiaridades importantes de serem ressaltadas para que possa se compreender de maneira mais específica o uso das variantes em foco neste trabalho, e que apenas podem ser evidenciadas com o cruzamento ou interação dos dados expostos, e a análise dos mesmos. Nesse sentido, esta parte do trabalho dedicar-se-á ao cruzamento e análise, por parte do pesquisador, desses aspectos que evidenciam mais a fundo as particularidades do fenômeno da variação entre as formas estudadas.

Nos subitens subsequentes, todos os condicionamentos linguísticos - posição sintática, tipo de construção, tipo de discurso - serão investigados relativamente aos dois condicionamentos sociais estipulados para este estudo, localidade e sexo/gênero. Pretendese, assim, produzir uma análise mais direta e mais esclarecedora do tipo de interação que favorece ou desfavorece o uso de uma ou mais variantes em determinado contexto linguístico motivado por algum aspecto de caráter social.

\subsubsection{POSIÇÃO SINTÁTICA}

\section{a) Localidade}

Em relação a esse aspecto linguístico, no que diz respeito à localidade, percebe-se, como evidenciado nos gráficos abaixo, uma grande tendência dos falantes de ambas localidades produzirem essencialmente as formas tu, você e cê em posição subjetiva: 

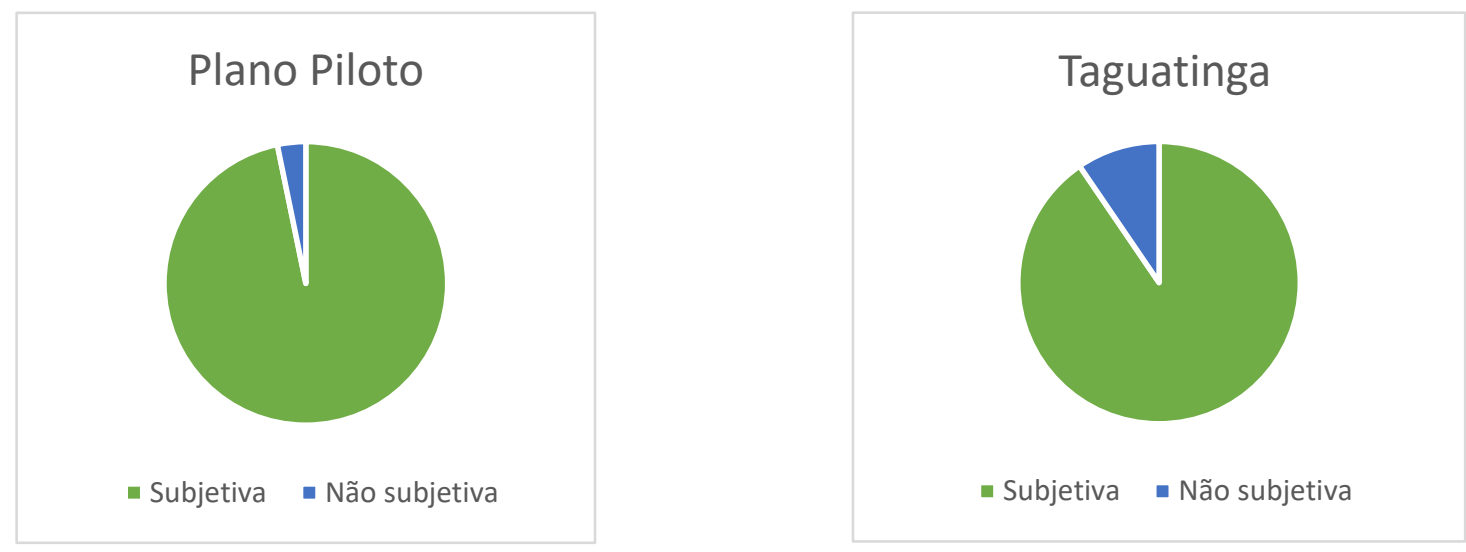

Uma pequena diferença pôde ser notada em relação aos falantes de Taguatinga utilizarem mais a posição não subjetiva na construção dos seus discursos, o que pode evocar, ao observar-se esse aspecto, certas especificidades relacionadas ao contexto social e histórico que envolvem a formação de ambas RA(s), tendo o Plano Piloto um contingente populacional mais abastado e, essencialmente, escolarizado, o que pode conferir mais segurança no ato de produção de fala desses participantes da pesquisa. Todavia, por ausência de estudos nesse sentido, essa é apenas uma inferência, havendo, também, a possibilidade dessa massiva utilização dos pronomes em posição subjetiva ser fruto dos tipos de discurso mais utilizados pelos falantes da pesquisa, o que alude ao imbricamento das diferentes variáveis linguísticas no ato de produção de língua, e à relevância de cada uma delas no estudo aprofundado dos fenômenos da língua.

\section{b) Sexo/Gênero}

Levando em consideração a variável social gênero, percebe-se alguma diferença em relação à variável enfocada no subitem anterior, como pode se observar nos gráficos a seguir:
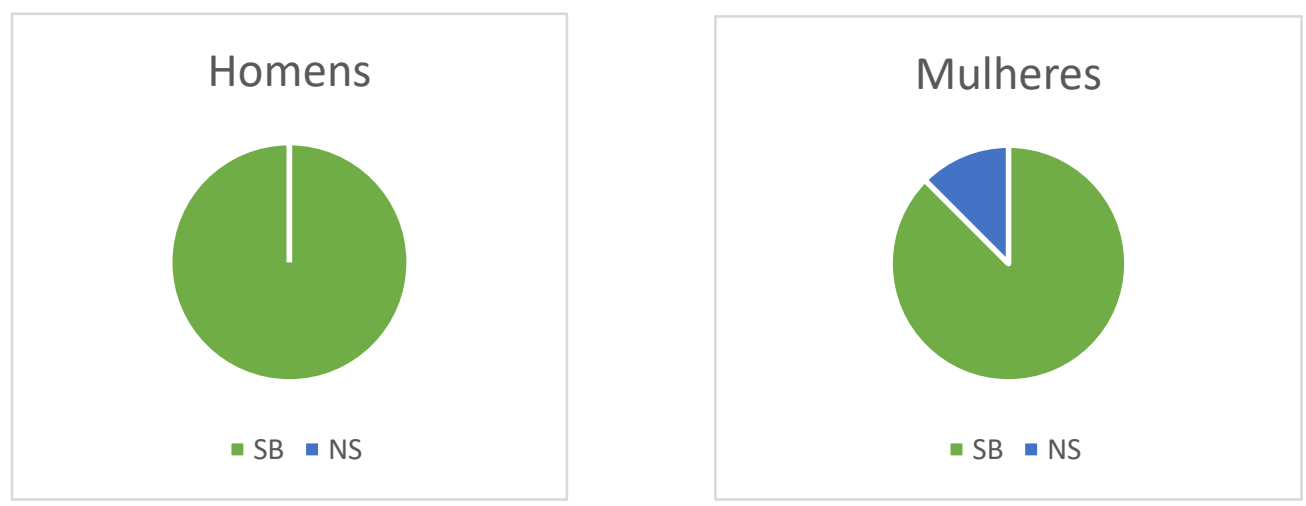
Quanto à utilização majoritária dos pronomes em posição subjetiva, houve paralelismo em relação à variável localidade. Todavia, fora perceptível que apenas mulheres, em ambas regiões, utilizaram os pronomes em posição não subjetiva nas entrevistas, tendo os homens participantes apenas utilizado a posição subjetiva em suas construções. Isso revela uma forte tendência de utilização da posição subjetiva nos contextos interacionais entre os pares linguísticos, tendo em vista o gênero do pesquisador em relação ao dos entrevistados, o que pode estar relacionado às marcas linguísticas de sexo/gênero, que conferem algumas particularidades à produção de língua nos contextos interacionais entre os falantes da língua, como, por exemplo, a polidez, ou mesmo as escolhas de formas que denotem proximidade ou distanciamento, como bem explica o capítulo Marcas Linguísticas de Polidez e Sexo/Gênero, de Santos e Araujo (2015), o qual afirma que:

Se outrora a diferença na fala de homens e mulheres estava relacionada ao papel desempenhado por cada um na sociedade, atualmente, em um momento em que indivíduos de ambos os sexos/gêneros desempenham os mesmos papéis sociais, as diferenças entre as formas de falar podem estar relacionadas a fatores pragmáticos (SANTOS; ARAUJO, 2015, p. 211)

\subsubsection{TIPO DE CONSTRUÇÃO}

\section{a) Localidade}

A análise dos dados relacionados ao tipo de construção das frases revelou uma preferência dos falantes pesquisados pelas frases afirmativas no uso dos pronomes tu, você e cê, com uma grande ocorrência desses pronomes, ainda, em sentenças interrogativas e explicativas, havendo apenas um registro de sentença exclamativa no corpus, como podese perceber no gráfico a seguir:

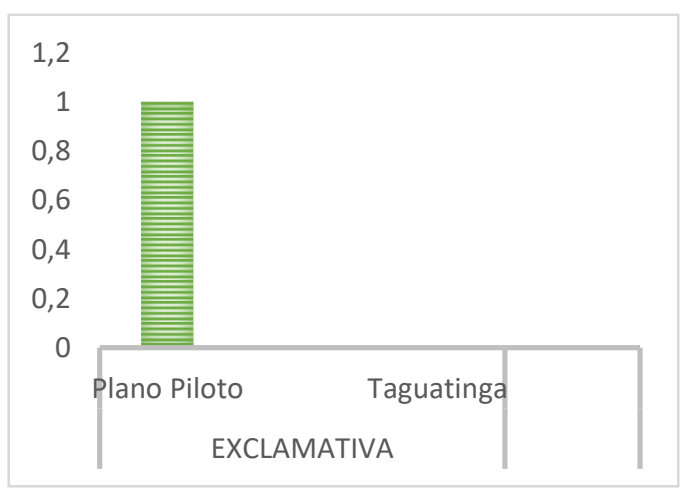


Assim sendo, pode-se perceber uma baixa tendência (com apenas 01 ocorrência), por parte dos falantes entrevistados, pelas sentenças exclamativas, e uma recusa pelos falantes de Taguatinga pela produção desse tipo de construção.

Nos registros dos falantes do Plano Piloto, também fora identificado maior uso das formas estudadas em sentenças explicativas e interrogativas. O paralelismo e vitória no uso dessas formas (10 ocorrências em cada aspecto, de 16 e 13 ocorrências gerais, respectivamente) no Plano Piloto, evidencia a preferência de uso desses falantes na produção desse tio de discurso, em face da baixa utilização em Taguatinga de ambos os tipos de construção (apenas 6 ocorrências em orações explicativas, e 3 em interrogativas). Isso pode demonstrar características inerentes aos falantes do Plano Piloto de reafirmação dos discursos afirmativos, no caso do primeiro conjunto de dados, relacionados à classe social à qual pertencem esses participantes, e ao contexto histórico que envolve a formação dessa região. Com relação às orações explicativas, o grande uso desse tipo de oração pode ser explicado pelo tipo de assunto preferido pelos informantes no momento da entrevista, que optaram por perguntar mais ao entrevistador, do que, de fato afirmarem suas histórias, como aconteceu com os falantes Taguatinguenses (vd. gráfico que ilustra as construções afirmativas). Entretanto, o confronto com o baixo uso das formas pronominais por parte dos falantes de Taguatinga, também pode evidenciar uma preferência discursiva maior relacionada a esse tipo de oração por parte desses participantes, em relação aos Taguatinguenses, que optaram majoritariamente pelo uso das estruturas afirmativas, quase execrando as construções interrogativas, pelo baixíssimo número de uso, como pode-se perceber no gráfico abaixo:
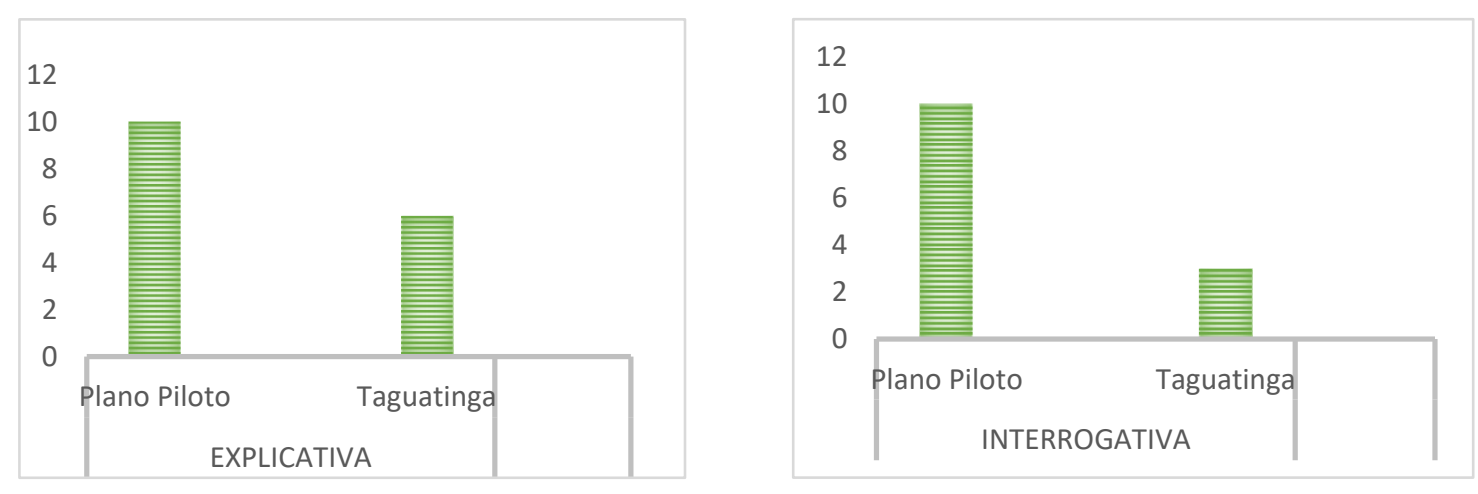

Os falantes de Taguatinga preferiram o uso das formas pronominais em estruturas afirmativas, sendo esse tipo de construção a que mais teve ocorrências documentadas, mesmo se somadas todas as outras ocorrências de pronomes em outros tipos de construções, como se pode aferir no gráfico a seguir: 


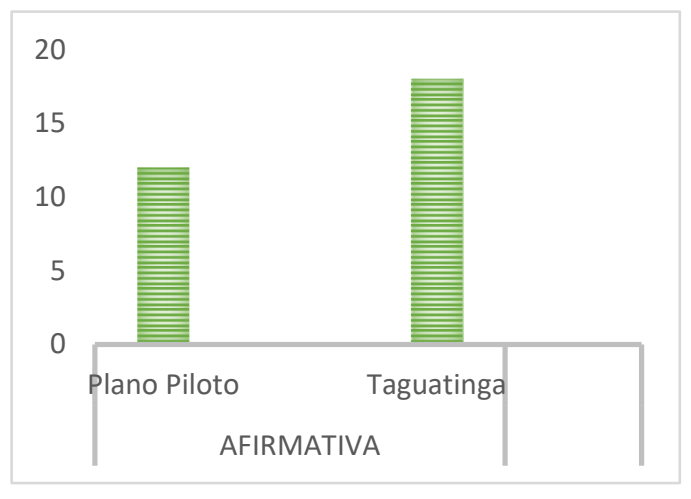

As preferências de utilização dos pronomes nos tipos de oração acima observados podem estar ligadas ao tipo de discurso empregado pelos falantes de cada região (aspecto que será abordado no próximo item), mas, para além disso, revela as tendências de favorecimento da presença pronominal nas diferentes estruturas nas regiões focalizadas, o que nos dá o panorama de tipo de oração mais empregada pelos falantes de cada uma delas. Ou seja, há uma tendência de maior utilização de orações afirmativas pelos falantes de Taguatinga, único tipo de estrutura que os falantes da região Taguatinguense preferiram, em relação ao Plano Piloto, com baixa ocorrência (sobretudo nas estruturas interrogativas, com apenas três ocorrências, das treze aferidas) dos pronomes em outros tipos de oração Um aspecto que merece destaque no que diz respeito ao discurso produzido na região Taguatinguense, é a escolha pela variante você em detrimento da cê, registrando, ainda, mais ocorrências de tu do que a região contrastada, aparecendo, esta forma, em contextos discursivos não-estigmatizados. Cabe, ainda, sublinhar que os falantes da região do Plano Piloto mantêm um certo paralelismo na utilização das formas em estruturas explicativas e interrogativas, a despeito de um ligeiro maior uso pronominal, como já dito, nas estruturas afirmativas, preferindo, no geral, em contextos discursivos o uso da forma cê, registrando, a despeito disso, grande ocorrência da forma cê, com um baixíssimo uso da forma $t u$, que apenas fora aferida em contextos discursivos reportados, de fala estigmatizada.

\section{b) Sexo/Gênero}

Quanto às especificidades dessa variável relacionadas ao sexo/gênero do falante, vê-se que única construção exclamativa presente no corpus fora produzida por uma falante do sexo feminino:

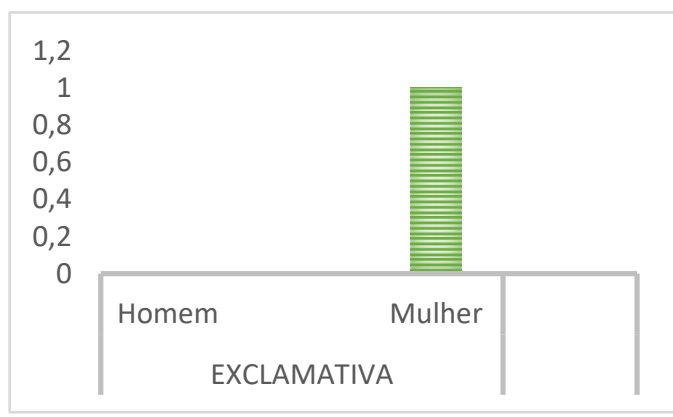


Já em relação às construções explicativas, percebe-se absoluto paralelismo na utilização das formas pronominais entre homens e mulheres, sendo o índice de utilização proporcional entre os falantes dos diferentes sexos, o que pode, também, estar ligado ao tipo de discurso utilizado pelos informantes nos contextos monitorados de fala, bem como da proeminência de sentenças explicativas em entrevistas, pela característica, muitas vezes, de informatividade desse tipo de método discursivo.

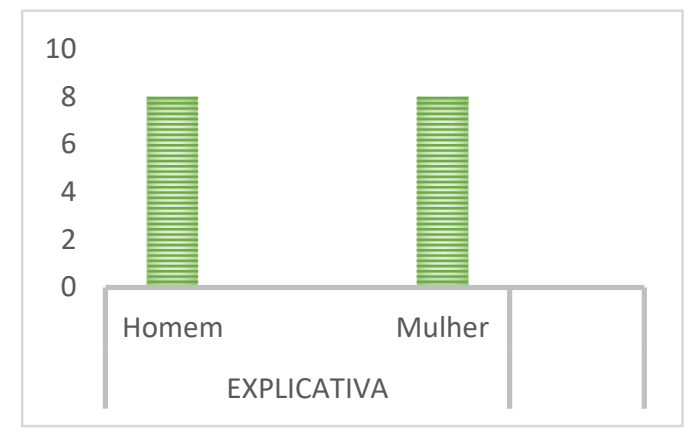

Nas orações interrogativas, percebeu-se uma maior tendência de utilização das formas pronominais por parte dos falantes homens, os quais registraram, dentro do universo destacado, mais que o dobro de ocorrências dessas formas do que os falantes do sexo feminino, o que pode ser motivado, mais uma vez evocando o conceito de marcas de polidez na fala relacionadas ao interlocutor, por uma preferência discursiva das falantes dos diferentes sexos, em face do gênero do interlocutor. Esta tese é endossada pela preferência, e vitória, das falantes mulheres pelas construções afirmativas (vd. gráfico que trata das estruturas afirmativas), uma marca discursiva de reafirmação perante um interlocutor masculino que contrasta com a massiva preferência dos falantes homens pelas sentenças interrogativas, como evidenciado na tabela abaixo:

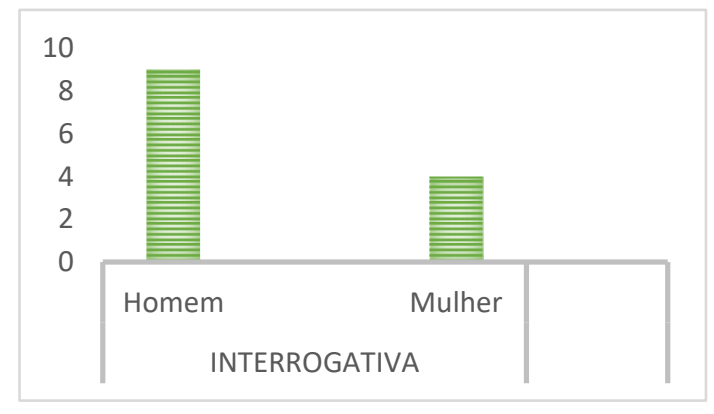

Quanto às construções afirmativas, como já tangenciado, percebeu-se relativo paralelismo na utilização das formas pronominais, tendo as falantes do sexo feminino 
aplicado ligeiramente mais as formas em suas orações afirmativas, em relação aos informantes homens:

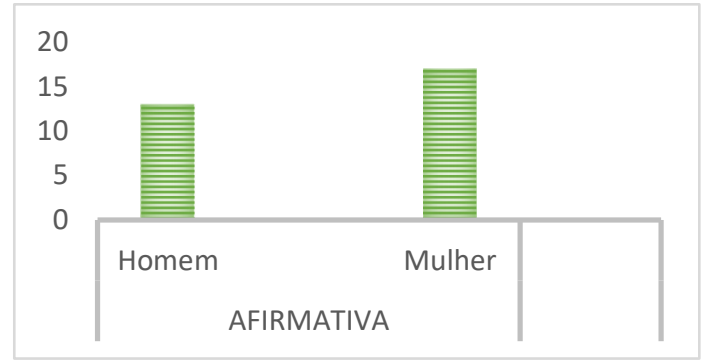

Assim sendo, é perceptível que as estruturas afirmativas favoreceram, no corpus analisado, a presença dos pronomes focalizados, havendo ligeiro paralelismo na utilização dessas formas nas sentenças explicativas e interrogativas. Ainda, vê-se absoluta paridade de uso entre homens e mulheres nas orações explicativas, preferência de uso por parte dos falantes homens nas construções interrogativas, em contraste com a preferência das informantes mulheres pela utilização dos pronomes em orações afirmativas, e baixo nível de utilização pronominal nas sentenças exclamativas, vencendo, nesse tipo de construção, a forma pronominal você, a exemplo das sentenças explicativas e afirmativas, que registraram uma massivo uso dessa mesma forma pronominal em relação às outras. Vale, também, destacar a forma cê, que fora a mais utilizada nas orações interrogativas, e relativamente competiu em utilização com o pronome você em todas as outras construções em que foi registrado, vide gráfico a seguir:

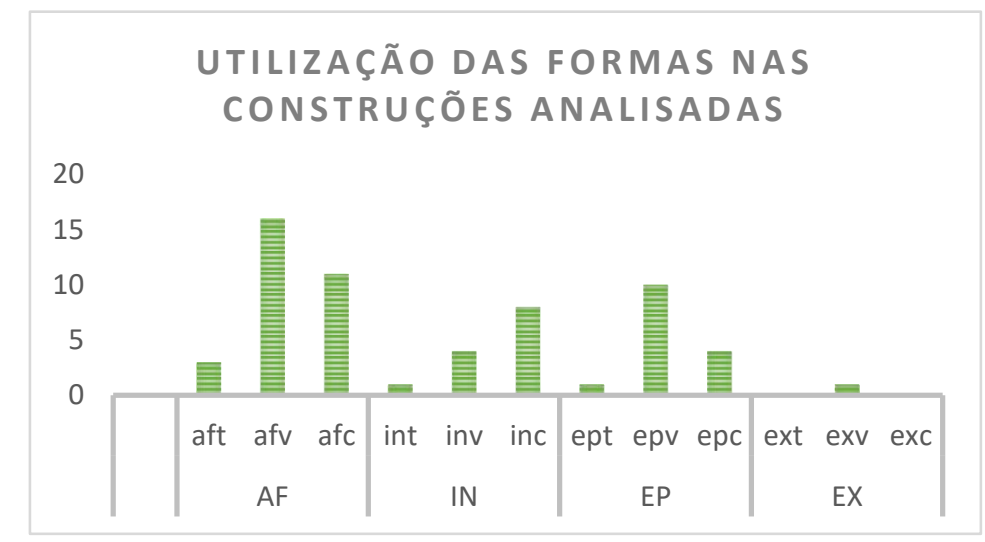

Isso sugere uma forte concorrência entre as formas pronominais cê e você em todos os tipos de construção, as quais sempre vencem em utilização se confrontadas ao tu, o que leva a crer ainda mais no patamar de estigmatização dessa forma pronominal em relação às outras, que a despeito da vitória do você na maioria dos tipos de construção analisados, ainda coocorre ao cê, vencedor nas estruturas interrogativas (sugerindo uma 
preferência de uso da forma em estruturas desse tipo) e significantemente registrado, mesmo nas orações que têm o você como preferido em utilização.

\subsubsection{TIPO DE DISCURSO}

\section{a) Localidade}

Quanto ao tipo de discurso, pôde-se observar que o discurso geral fora mais utilizado em ambas regiões, bem como houve grande concorrência de uso dos discursos indireto e direto, tendo os informantes do Plano Piloto preferido o discurso direto em detrimento do indireto, contrastando com os de Taguatinga que, entre esses dois tipos específicos de discurso, preferiram o indireto, mesmo que com uma pequena diferença de uso entre um e outro. Abaixo, seguem os gráficos que ilustram tais afirmações:
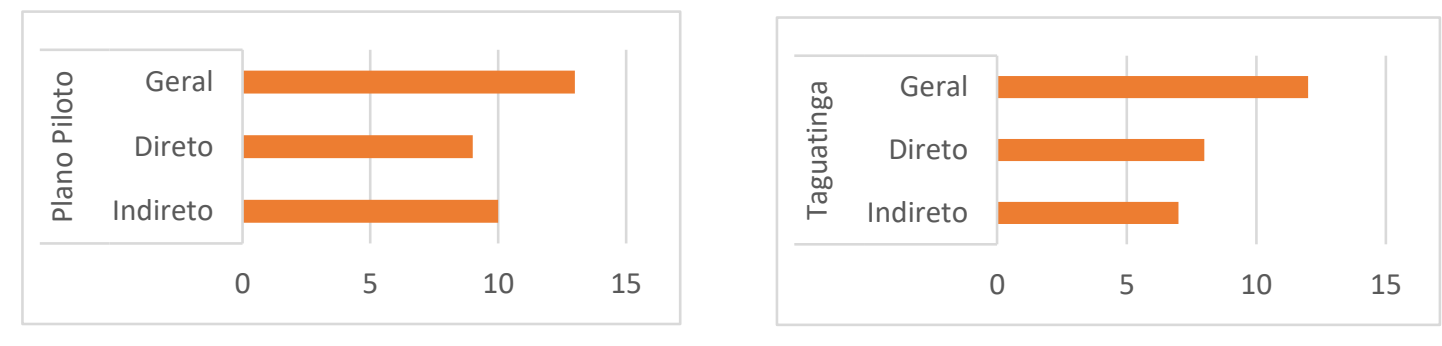

Assim sendo, percebe-se a preferência por parte dos falantes de ambas regiões pelo uso do discurso geral em detrimento dos outros tipos analisados. Tal escolha pode ser tomada como uma característica dos recursos discursivos relacionados ao tipo de coleta de dados, obtidos por meio de entrevistas, mas, ainda, pode revelar uma tendência de utilização das formas pronominais tu, você e cê como um recurso de fala característica de construções explicativas ou afirmativas com interlocutores não-próximos.

Fora percebido, dessa forma, nos dados coletados, grande disputa entre as formas você e cê, um indício de mudança da forma cristalizada (você) para uma monossilabiedade, já apontada por Silva (2009), como uma característica de evolução das formas pronominais. Cabe salientar a vitória de utilização da forma você nos contextos de fala dos falantes do Plano Piloto, e do cê entre os falantes da região de Taguatinga, por uma diminutíssima margem (vd. Tabelas 1 e 2), além da vitória do você nos períodos onde houve paralelismo de uso das formas (vd. Tabela 5). 


\section{b) Sexo/Gênero}

No que se refere à variável sexo/gênero, percebe-se clara preferência dos falantes homens pela utilização do discurso geral, em detrimento dos outros tipos discursivos, como se observa no gráfico abaixo:

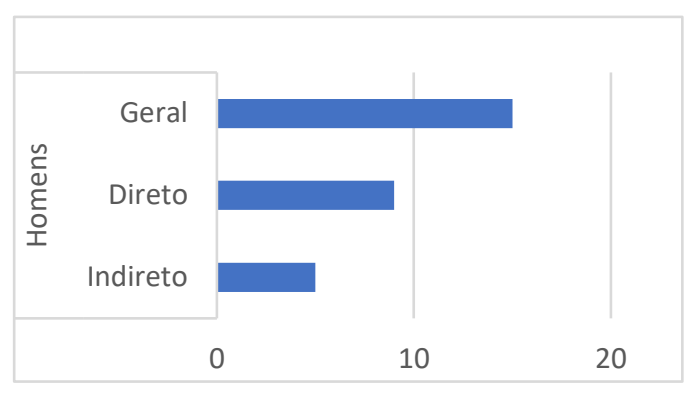

Já as falantes do sexo feminino, por sua vez, demonstraram preferência pelo discurso indireto, contrastando com a tendência geral de utilização aferida, que demonstrou uma maior proeminência de utilização pronominal nos discursos diretos, o que pode ser interpretado como uma marca de polidez, apoiando-se na literatura de Santos e Araujo (2015), que esclarece, no que diz respeito às marcas de polidez relacionadas ao gênero, que "Brown e Levinson (2011 [1987]) concebem a polidez como uma atividade estratégica racional e defendem que as diferentes formas de polidez atendem às diferentes necessidades sociocomunicativas". Ou seja, a preferência de utilização dos discursos indiretos por parte das falantes femininas pode ser concebida como uma dessas marcas de polidez, bem como um recurso de fala desse grupo linguístico, que pode combinar-se com o fator de distanciamento discursivo por polidez, gerando os dados aferidos no gráfico abaixo:

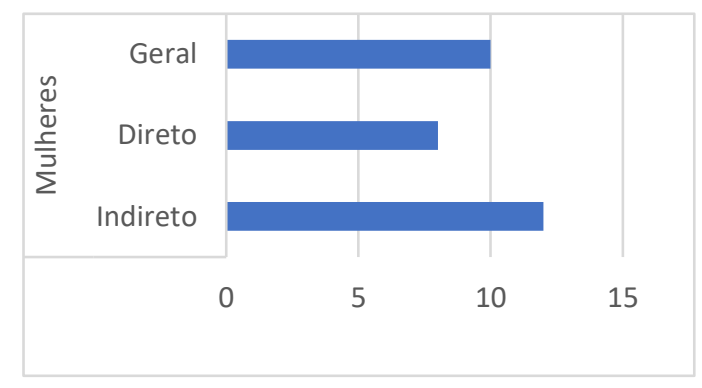

Portanto, percebe-se, a despeito das especificidades discursivas inerentes aos diferentes sexos supracitadas, que no que diz respeito às características de utilização das formas pronominais por parte dos grupos de fala focalizados, há uma preferência pelo 
discurso geral ou indireto (se observada a assimetria de utilização presente entre as falantes do sexo masculino e feminino). Essa preferência evidencia uma tendência de utilização dos pronomes de segunda pessoa nos discursos impessoais, como uma marca discursiva dos falantes do português candango, propensão também aferida, no que diz respeito ao uso das formas pronominais no português, por Penkal (2013, p. 77, apud BENVENISTE, 1995, p. 279), que diz: "eu é transcendente ao tu e é interno ao enunciado, mas a transcendência e a interioridade podem inverter-se em $t u$, desde que tu passe a ser eu".

Ou seja, tomando, no texto de Penkal, a palavra "tu" pela segunda pessoa do singular, pode-se perceber que há propensão de utilização dessa categoria pronominal como um recurso que funciona como uma espécie de "espelhamento de subjetividade", que se expressa, pela natureza desses enunciados, nos discursos gerais e impessoais, o que corrobora a proeminência do tu, você e cê nesses tipos discursivos dentre os dados coletados na presente pesquisa.

Nesse sentido, como apontam os dados, percebe-se que a comunidade de fala do Plano Piloto rejeita a forma tu mais do que os falantes da região Taguatinguense, o que revela um patamar de estigmatização dessa forma, que pode ser motivado pelos fatores sociais relacionados ao estrato econômico ao qual pertence a maior parte dos interlocutores da pesquisa (vd. Contexto histórico e social das regiões estudadas). Entretanto, ainda em se tratando dessa forma pronominal, corroborando os estudos de Scherre (2011), os falantes do sexo masculino, a despeito da baixa ocorrência dessa forma pronominal nos dados coletados, tendem a sistematicamente utilizar mais o tu em contexto interacional, do que as falantes mulheres, o que demonstra preferências discursivas relacionadas não apenas às regiões mas ao sexo dos interlocutores, bem como da natureza desses discursos, os quais, como visto nos gráficos deste capítulo, demonstram a preferência do discurso Geral nos contextos interacionais em ambas regiões, com pequenas especificidades relacionadas ao gênero do falante. 
"A loucura chegou a tanto e portanto, no entanto por enquanto resta a gramática e o estruturalismo um abismo de interpretações complexas, inúteis, ... não passam de aspiração ao Eterno"

- Murilo Vieira Komnisky

\section{CONSIDERAÇÕES FINAIS}

Conclui-se, portanto, a presente pesquisa, alcançando seus objetivos de análise das ocorrências e peculiaridades das formas tu, você e cê em Taguatinga e no Plano Piloto, constatando forte concorrência e coocorrência das formas "você" e "cê", e ressaltando a presença, ainda, do pronome "tu", que demonstrou baixa ocorrência entre os falantes da pesquisa, sinalizando indícios de certa estigmatização por parte dos informantes do Plano Piloto, a despeito de sua presença nas construções dos falantes da região de Taguatinga, sendo preferido pelos homens de tal localidade. É importante complementar que, em todo o estudo, observou-se relativa paridade entre os usos das variantes você e cê e, por outro lado, certa esquiva em relação ao uso do pronome tu. Neste ponto, cabe ressaltar que essa última variante, talvez, possa representar um uso inovador da segunda pessoa nessa variedade em contraste com o Português Brasileiro em geral ou, ainda, a renascimento de uma forma tradicional de antigos falantes de outras regiões brasileiras que vieram para Brasília e, aqui, deram origem a novas gerações de falantes no coração do Planalto Central.

Vale sublinhar, ainda, que no que diz respeito às formas vencedoras em concorrência (você e cê), leva em utilização ligeira vantagem a forma "você", predileta entre os falantes de Taguatinga [vd. Tabela 2], também preferida em utilização pelas pessoas do sexo/gênero masculino e feminino, e, ainda, a mais utilizada em períodos que exigem paralelismo de uso das formas. Entretanto, é pertinente, ainda, destacar a forma "cê", preferida entre os falantes do Plano Piloto [vd. Tabela 1] e sempre concorrente ao "você", com marcante presença e utilização nos diferentes discursos, entre homens e mulheres, sendo a forma predileta nas construções explicativas, tendo um alto registro nos números gerais de ocorrência das formas [vd. Tabela 3].

Assim, como revelam os estudos Saussureanos, bem como apregoa, primordialmente, o estudo sociolinguístico, a língua é um construto social, um aspecto 
indivisível da vida em sociedade, e compreender como se dá sua utilização nos contextos interacionais, pode nos dizer como se comportam os diversos elementos identitários que constituem a cultura de determinado povo. Nesse sentido, o presente trabalho pôde constituir significativo panorama no que diz respeito à utilização dos pronomes na variedade do português falado no Distrito Federal, principalmente se levadas em consideração as especificidades linguísticas dos grupos focalizados, e da geração à qual pertencem esses grupos, intermediários, de falantes de classe média e classe média alta escolarizada. Esses grupos, como já tangenciado nos trabalhos de Faraco $(1991 ; 2008)$, podem demonstrar o patamar de utilização da língua, como um retrato dela na sociedade destacada, bem como explicitam especificidades inerentes à variedade brasiliense do Português Brasileiro (PB).

É valido, novamente, ressaltar que os aspectos de uso linguístico avaliados nesta pesquisa estavam condicionados, sobretudo, a momentos monitorados de fala, florescendo, principalmente, períodos mais formais de fala, pela característica das entrevistas, gravadas com conhecimento e consentimento dos participantes. Tendo isso em vista, necessárias são pesquisas futuras que primem pela captação de momentos informais e não monitorados de fala, para que a partir do cruzamento dos dados, levando em consideração ambas modalidades, formal e informal, de discurso, possa-se obter resultados mais conclusivos em relação à variedade de língua falada em tais regiões, componente imprescindível para um mais categórico panorama da variedade candanga do português.

Enquanto pesquisador, fazendo uso de formalíssima licença poética, concluo o presente trabalho ávido por mais desafios, anelante pela construção conjunta, sobre os oblíquos ombros do conhecimento, de um completo panorama da variedade linguística do português brasiliense: essa tão desafiadora e intrigante aventura pelos vértices enigmáticos da língua de nossa jovem capital, a última pétala da última flor do Lácio. 


\section{BIBLIOGRAFIA}

ALVES, Cibelle Corrêa Béliche. O uso do tu e do você no português falado no Maranhão. Diss. Dissertação de Mestrado. Fortaleza, Universidade Federal do Ceará, 2010.

AMARAL, Luís I C. A concordância verbal de segunda pessoa do singular em Pelotas e suas implicações lingüísticas e sociais. Tese. Tese de doutorado. Porto Alegre, UFRGS, 2003.

ANDRADE, Carolina Queiroz. Tu e mais quantos. A segunda pessoa na fala brasiliense. Brasília: Universidade de Brasília (Dissertação de Mestrado), 2010.

BAGNO, Marcos. Nada na língua é por acaso: por uma pedagogia da variação linguística. Parábola, 2007.

BECHARA, Evanildo. Moderna Gramática Portuguesa: 37ª edição atualizada pelo novo Acordo Ortográfico. Rio de Janeiro, Nova Fronteira: 2009.

CHAGAS, Paulo. "A mudança lingüística". In: FIORIN, J.L. (Org.) Introdução à Lingüística I: Objetos teóricos. São Paulo: Contexto, 2002.

CUNHA, Celso; CINTRA, Luís. F Lindley. Breve gramática do português contemporâneo. Edições João Sá da Costa, 1998.

DA SILVA MENON, Odete Pereira. O sistema pronominal do português do Brasil. Revista letras, v. 44, 1995.

DETTONI, Rachel do Valle. "A concordância de gênero no falar cuiabano: a trajetória de uma mudança linguística em curso". In: Vozes cuiabanas: estudos linguísticos em Mato Grosso. Cuiabá: Cathedral (2005): 51-67.

DIAS, Edilene Patrícia. O uso do tu no português brasiliense falado. Diss. Dissertação (Mestrado em Linguística). Instituto de Letras, Universidade de Brasília, Brasília, 2007. FARACO, Carlos Alberto. "Por uma pedagogia da variação linguística". A relevância social da linguística: linguagem, teoria e ensino. São Paulo: Parábola Editorial (2007): 21-50.

FARACO, Carlos Alberto. Lingüística histórica. São Paulo: Ática, 1991.

FARACO, Carlos Alberto. Norma culta brasileira: desatando alguns nós. Vol. 25. Parábola, 2008.

LABOV, W. Principles of Linguistic Change. Oxford/Cambridge: Blackwell, 1994. 
LEITE, M Q. A Norma Linguística: Conceito e Características (Texto Inédito). São Paulo: USP, s/d.

LOPES, Celia Regina Dos S. Retratos da variação entre "você" e "tu" no português do Brasil: sincronia e diacronia. In: Claudia Roncarati; Jussara Abraçado. (Org.). Português Brasileiro II - contato lingüístico, heterogeneidade e história. 1 ed. Niterói: EDUFF, 2008, v. 2, p. 55-71.

LOREGIAN-PENKAL, Loremi. (Re) análise da referência de segunda pessoa na fala da Região Sul. Tese. Tese de Doutorado. Curitiba, Universidade Federal do Paraná, 2004. LOREGIAN-PENKAL, Loremi. Pronomes pessoais: conceituação versus uso. UNICENTRO, 2013.

LOREGIAN-PENKAL, Loremi; DA SILVA MENON, Odete Pereira. Você, Ocê (?) e Cê em Curitiba, Paraná. In: Signum: Estudos da Linguagem, v. 15, n. 1, p. 223-243, 2012.

LUCCHESI, D; ARAÚJO, S. A teoria da variação linguística. Bahia, Vertentes do português popular do Estado da Bahia. Disponível em:< http: www. vertentes. ufba/a-teoria-davariaçãolinguística.>. Acesso em: 07/12/2017.

MATTOS, Shirley Eliany Rocha. Goiás na primeira pessoa do plural. 2013.

NEGRÃO, E; SCHER, A; VIOTTI, E. “A competência Lingüística” In: FIORIN, J.L. (Org.) Introdução à Lingüística I: Objetos teóricos. São Paulo: Contexto, 2002.

PERINI, M A. Quadro geral do português do Brasil hoje. In: Os contatos linguísticos no Brasil. Mello, H; Altenhofen, C V; e Raso T (Orgs.). editora UFMG, Belo Horizonte, 2011. PINTZUK, S. VARBRUL programs. Ms, 1988.

ROCHA LIMA, Carlos Henrique Da. Gramática normativa da língua portuguesa: Edição revista segundo o novo Acordo Ortográfico (49ª Edição). Rio de Janeiro: J. Olympio, 2011.

ROCHA, Patrícia Graciela Da. " $A$ variação dos pronomes de segunda pessoa na língua falada nas comunidades de Ratones e de Santo Antônio de Lisboa: uma abordagem sociolinguística variacionista". Working Papers em Linguística 11 (2010): 69-81.

SANTOS, Kelly Carine dos; ARAUJO, Andréia Silva; "Marcas linguísticas de polidez e sexo/gênero", p. 209-224 . In: Freitag, Raquel Meister Ko.; Severo, Cristine Gorski (Org). Mulheres, Linguagem e Poder - Estudos de Gênero na Sociolinguística Brasileira. São Paulo: Blucher, 2015. 
SCHERRE, M M P. "Padrões sociolinguísticos do português brasileiro: a importância da pesquisa variacionista". Tabuleiro de Letras 4 (2012).

SCHERRE, M M P; DIAS, E P; ANDRADE, C Q; LUCCA, N N G; \& de ANDRADE, A L V S. (2012). Tu, você, cê e ocê na variedade brasiliense. In: PAPIA-Revista Brasileira de Estudos do Contato Linguístico, 21(esp.), 117-134.

SCHERRE, M M P; YACOVENCO, Lilian Coutinho. A variação linguística e o papel dos fatores sociais: o gênero do falante em foco. Revista da ABRALIN, v. 10, n. 3, 2011.

SILVA, Rita do Carmo Polli da. A sociolinguística e a língua materna. Curitiba: Ibpex, 2009.

SILVA, Vera Lúcia Paredes. "Variação e funcionalidade no uso de pronomes de $2^{a}$ pessoa do singular no português carioca". In: Revista de Estudos da Linguagem v. 7, n. 2: 121-138, 1998. 